\title{
CIVIL JUSTICE DISCRETION CONSCIOUSNESS MINDFULNESS
}

Olga Nickole Kuyan (Papkova) ${ }^{1}$

\author{
${ }^{1}$ Affiliation not available
}

February 16, 2023 
CIVIL JUSTICE, DISCRETION, CONSCIOUSNESS, MINDFULNESS. THROUGH LEGAL PUZZLES, SCIENCE, ART, AND DECOLONIALITY OF KNOWLEDGE.

\begin{abstract}
Justice is as important as health, education. Justice is alpha value in the spheres of law and politics. Civil justice remains in constant flux. The design of a sustainable civil justice system for the 21 st century is continuously discussed at national, EU, and international level.

This article makes the part of the research, started in 1990 with the study of Judicial Discretion in Civil Procedure, continued in different ways, with the scrutiny of the Compensation for nonmaterial damages in Italy and Russia at UNIPV with Prof.Carlo Granelli, in particular. It begins from the hypothesis that the civil justice may be achieved not only through lawljudicial reforms but also through the mindfulness, may be researched not only through law and politics but also through sciences. We use the Complex Thinking concept; Art and Quantum Theory as Puzzles.

We scrutinize into the conventional existence of civil justice which can be achieved in various forms of political settings - democratic as well as non-democratic - in every trial, under the rule of law.

The main question of this article is: what does conventional existence of Civil Justice depend upon? We put forward the idea about the evolution towards Wellbeing, Justice through Mindfulness, using the term Evolution in J.J. Hurtak's sense: spiritual evolution.

This article refers to the decoloniality to re-learn the thoughts-heritage that have been pushed aside, buried, discredited by the forces of modernity. So, we refer to the ideas of Ivan Ilyin, named Putin's Philosopher of Russian Fascism by T.Snyder.

The article will not only shed light on the nature of the political order in Russia but will also give a useful contribution to the scholarly discussion on the mindfulness, within the Civil Justice that is explicitly new view.
\end{abstract}

Key words: I.Ilyin, Conventional existence of Civil Justice, Political Regime, Russian Constitution, Discretion, Science, Holographic Universe Theory, Interaction, Consciousness, Legal Consciousness, Mindfulness. 


\section{Introduction}

Justice is as important as health or education. ${ }^{1}$ Justice is one of the most important moral values in the spheres of law and politics. Legal and political systems that maintain law and order are desirable, but they cannot accomplish either unless they also achieve justice. Law and Judicial reforms are in progress in many countries. But Civil Justice ${ }^{2}$ has no existence. ${ }^{3}$ Not all countries' judiciaries operate at the same level of efficiency. ${ }^{4}$ Why?

To respond this question we don't follow the idea of US Chief Justice John Marshall who in 1824 wrote: "Judicial power, as contradistinguished from the power of the laws, has no existence. Courts are the mere instruments of

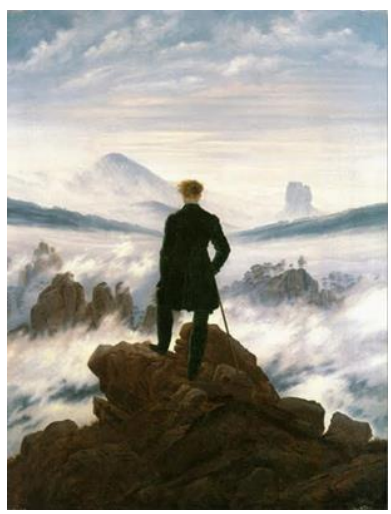
the law, and can will nothing. When they are said to exercise discretion, it is a mere legal discretion, discretion to be exercised in discerning the course prescribed by law; and, when that is discerned, it is the duty of the court to follow it. Judicial power is never exercised for the purpose of giving effect to the will of the judge, always for the purpose of giving effect to the will of the legislature; or, in other words, to the will of the law." ${ }^{, 5}$ Following the ideas of Nagarjuna ${ }^{6}$, J.L.Garfield ${ }^{7}$, Carlo Rovelli $^{8}$, we put into discussion that the Civil Justice has no existence in itself ${ }^{9}$. Starting from the

\footnotetext{
${ }^{1}$ See in detail: https://www.lawgazette.co.uk/law/justice-as-important-as-health-or-education-public/5068080.article : According to the survey of 2,086 people, more than three-quarters agreed that justice is as important as health of education. A similar figure agreed that people on low incomes should be able to get free legal advice. The survey highlights a widespread belief that the justice system is tilted in favour of the wealthy. Nearly two-thirds of respondents would feel uncomfortable dealing with the law and legal processes. For all types of legal issues listed in the survey, at least half of respondents said they would feel uncomfortable dealing with them without a lawyer. Law Society president Christina Blacklaws said: 'Cuts to legal aid spending over the past five years have denied justice to the most vulnerable in society, placed a further burden on the taxpayer and damaged the foundation of our justice system. Since April 2013, hundreds of thousands of people have become ineligible for legal aid as a result of freezes to means tests as well as cuts to the scope of legal aid, including victims of domestic abuse and people under threat of eviction.'

${ }^{2}$ We intend formal and informal civil justice.

${ }^{3}$ In the latter part of the 20th century a number of aspects of the adversarial system of justice have been questioned, http://www.austlii.edu.au/au/journals/NSWJSchol/2010/5.pdf

${ }^{4}$ Cross-country differences in average trial length appear to be large, though international comparisons also reflect dissimilarities in the systems and in the way court statistics are collected in different countries. In 2010 the average length of civil proceedings in first instance (-) was around 240 days, but only 107 days in Japan, the best performer. About 420 days were required in Slovenia and Portugal, and 564 days in Italy. The average length of a civil dispute going through all three instances was 788 days, ranging from 368 days in Switzerland to almost 8 years in Italy (Figure 1 and Annex Table, https://www.oecd.org/economy/growth/Civil\%20Justice\%20Policy\%20Note.pdf . Here is the OECD research which provides cross-country comparison on the wide variation in judicial efficiency in 35 legal systems worldwide covering jurisdictions of 33 countries -- including measures of trial length, accessibility to justice services and the predictability of decisions).

${ }^{5}$ Osborn v. Bank of the United States, 22 U.S. 738 (1824), https://supreme.justia.com/cases/federal/us/22/738/

${ }^{6}$ Nāgārjuna (c. 150 - c. 250 CE) is widely considered one of the most important Buddhist philosophers. The term used by Nagarjuna to describe this lack of self-essence is "emptiness" (sunyata): things are "empty" in the sense that they have no autonomous reality, they exist thanks to, as a function of, with respect to, from the perspective of something. On the other hand Nagarjuna distinguishes two levels, as do so many philosophy and science: conventional reality, apparent, with its illusory or perspective aspects, and ultimate reality. But it takes this distinction in a surprising direction: the ultimate reality, the essence is absence, emptiness.

${ }^{7}$ Jay L. Garfield describes that Nāgārjuna approached causality from the four noble truths and dependent origination. Nāgārjuna distinguished two dependent origination views in a causal process, that which causes effects and that which causes conditions. This is predicated in the two truth doctrine, as conventional truth and ultimate truth held together, in which both are empty in existence. The distinction between effects and conditions is controversial. In Nāgārjuna's approach, cause means an event or state that has power to bring an effect. (Garfield, Jay L, Dependent Arising and the Emptiness of Emptiness: Why Did Nāgārjuna Start with Causation?, Philosophy East and West. 44 (2): $219-50$ (April 1994)

${ }^{8}$ Carlo Rovelli is an internationally renowned theoretical physicist who during his career has worked mainly in the field of quantum gravity and was one of the founders of the theory of loop quantum gravity. Carlo Rovelli also deals with the history and philosophy of science. In Helgoland Rovelli delves into revolutionary theory, first allowing us to
} 
Nāgārjuna's : "Emptiness ${ }^{10}$ [is] the essence of compassion" ${ }^{11}$ we suppose that Emptiness (no-self) is the essence of Justice; and we put it into discussion, too.

To deal with the emptiness (no-self) conceived by Buddhism in relation to the theories of quantum physics was the Italian physicist Carlo Rovelli, ${ }^{12}$ who, according to a common opinion among physicists who deal with quantum mechanics, affirms that the doctrine of emptiness as conceived in particular by the Buddhist monk Nāgārjuna, who takes it directly from the teachings of Buddha Sakyamuni or simply Buddha ${ }^{13}$ is identical to the way that quantum physics has of conceiving reality. In fact, the Buddha affirmed that all things are empty of intrinsic existence, that is, that all things exist not by themselves but because they are in relation to something else; quantum physics essentially says the same thing and that is that objects appear to exist only when they affect other objects.

We start from three points:

- 'Justice' ${ }^{14}$ has always been a sacred word for humankind. Within the Platonism, it has been argued that Justice is a virtue ${ }^{15}$. Many centuries later, Rawls looked at justice as at 'the first virtue of social institutions' ${ }^{16}$ We affirm that the doctrine of emptiness ${ }^{17}$ (no-self) as conceived in particular by Carlo Rovelli, who takes it directly from the teachings of Buddhist monk Nāgārjuna is identical to the way that lawyers have of conceiving justice. "All dharmas ${ }^{18}$ are characterized by emptiness". Inter alia, "dharma characterizes those personal actions that generate or maintain the cosmic order". ${ }^{19}$ Ultimately the term Dharma rises to the meaning of "truth" and "justice". We are sure that a common opinion among lawyers who deal with justice is "Justice is characterized by emptiness". - Be that as it may, in today's world there is still much controversy going on about the access to justice; the reality of justice. If we see access to justice as reality (as human right), the same justice should be reality. All of reality is interaction. ${ }^{20}$ Civil Justice is interaction. ${ }^{21}$

understand its theoretical and practical value, and then exploring the issues that make quantum theory one of the most mysterious physical theories science has to do with. These mysteries have been at the center of the research of physicists, philosophers and other great thinkers for years: Rovelli focuses on the relational interpretation and on the links between this interpretation and oriental history, art, literature and philosophy. The author leads to discover how this view of quantum theory can lead us to reconsider the way in which we think about reality.

${ }^{9}$ Because nothing has existence in itself.

${ }^{10}$ Śunyatā could be translated as vacuity, and sometimes voidness, also. A common translation is "no-self", without a self, the Pāli Canon (The Pāli Canon or Tipițaka is the oldest collection of Buddhist canonical texts. It is the pillar of Theravāda Buddhism and is currently practiced in Burma, Thailand, Cambodia, Laos and Sri Lanka. See in details: Lewis R. Lancaster in Buddhist Literature: Canonization, Encyclopedia of Religion, 331-6 (1986)) uses anattā as a singular substantive, meaning "not-self"(See; Bronkhorst, Johannes , Buddhist Teaching in India, Wisdom Publications, 124 (2009).

11 "Śūnyatā karuṇā garbham"

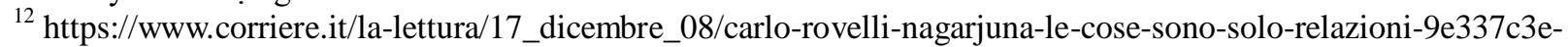
dc35-11e7-96bf-2722fd237ccc.shtml

${ }^{13}$ Lumbini, 8 April 566 BC - Kushinagar, 486 BC, he was a Buddhist monk, philosopher, mystic and Indian ascetic, founder of Buddhism, one of the most important spiritual and religious figures in Asia.

${ }^{14}$ See in detail: Justice, one of the most popular courses taught at Harvard College: https://justiceharvard.org/justice/, and https://plato.stanford.edu/entries/justice/

${ }^{15}$ Plato, Republic, translated and with intro by R.E. Allen, New Haven: Yale University Press, 24 (2006)

${ }^{16}$ Rawls, John, A Theory of Justice, Cambridge, MA: Harvard University Press, 3 (1971). Rawls was best known for this work (1971), a book that transformed how political philosophy was done for a generation. His philosophical vision of a just society, which embodied the postwar liberal dream of a more perfect America, became the basis for a philosophy known as "liberal egalitarianism." (see on liberal egalitarianism in detail: Tungodden Bertil and Cappelen Alexander, A Liberal Egalitarian Paradox, in Economics and Philosophy vol. 22 no. 3, 393-408 (2006))

${ }^{17}$ Sunnyatā (tr.eng. Emptiness) is a feminine noun of the Sanskrit. which indicates one of the fundamental doctrines in Buddhism. See: http://sanskritdictionary.com/?q=\%C5\%9B\%C5\%ABnyat\%C4\%81\&iencoding=\&lang

18 "Dharma" is a term that refers to many meanings, among which the main ones are: 1) teaching a systematic knowledge; 2) conducted according to justice; 3) causal condition; 4) phenomenon, effect; 5) ultimate Reality (Tathata).

${ }^{19}$ Mahony, William K. Hinduism, Encyclopedia of Religions, vol. 9: "Hindu Dharma". Milan, Jaca Book (2006).

${ }^{20}$ Carlo Rovelli: All Reality Is Interaction. See: https://onbeing.org/programs/carlo-rovelli-all-reality-is-interaction/ 
- Civil Justice should be achieved ${ }^{22}$ in every civil trial, for individual parties (person or group). Civil Trial is the Civil Procedural Relations. Interaction (Civil Justice) is different from Civil Procedural Relations in trial. The difference is that Civil Justice is the situation or occurrence in which two or more key figures or events act upon one another to produce a Civil Justice effect; the effect resulting from such a situation or occurrence while civil procedural relation is the manner in which key figures may be associated. Civil Justice is the content; Civil Procedural Relations are the form. The content is not empty, ever. Also Torricelli, removing the air from a bottle, shows that inside the bottle there are still many physical entities: electric and magnetic fields, and a continuous swarm of quantum particles. 23

We utilize Mead's theory ${ }^{24}$ to conceptualize Civil Justice as interaction. There are the intricate ways in which both courts and court participants come to reflect upon themselves from each others' perspectives. Here we don't promise to explicate exactly how this integration arises. For the purpose of this article it is enough to say that there is something that produces this interaction (Civil Justice). We want to find the connecting something that allows justice to act, to be produced:

a) Through civil procedural form;

b) Through gradual development;

c) In the courtroom;

d) By the method of manifestation.

If we carefully analyze these four points, we will find that they are quite understandable and represent the four means available to modern judge.

Judge is a person. If he sees himself as a synthetic combination of a physical body, emotional nature and mentality, ${ }^{25}$ is it enough for civil justice to be produced? We are looking for something that serves as a mediator for justice, through which it can be produced in a trial.

Et sic, conventional existence of Civil Justice ${ }^{26}$ is not denied, it is affirmed in all its complexity, with its levels and facets in every trial. It can be studied, explored, analyzed from different

\footnotetext{
${ }^{21}$ The term interaction is field-defining, yet surprisingly confused. This essay discusses what interaction is: Hornbæk Kasper, Oulasvirta Antti, What Is Interaction? (2017): https://www.researchgate.net/publication/313859745_What_Is_Interaction

${ }^{22}$ The article does not discuss the Aristotle's taxonomy of justice in the Nicomachean Ethics, three kinds of justice distributive justice, rectificatory or corrective or commutative justice, and reciprocal justice - and the difference between natural justice and conventional justice and uses the term "Conventional" in the sense of Nagarjuna and Carlo Rovelli.

${ }^{23}$ Torricelli's experiment was invented in Pisa in 1643 by the Italian scientist Evangelista Torricelli (1608-1647), an Italian physicist and mathematician, and a student of Galileo. He is best known for his invention of the barometer.

${ }^{24}$ This book presents a rigorous empirical exploration of the ideas of George Herbert Mead: Gillespie Alex, Becoming Other: From Social Interaction to Self-Reflection, Information Age Pub Inc, (2006).

${ }^{25}$ The presence of the mind, body, emotions and spirit as foundational of human beings has been accepted by some (especially indigenous) cultures for thousands of years (Meadows, K. The medicine way: A shamanic path to selfmastery. Dorset, England: Element Books (1992); Mehl-Madrona, L. Coyote medicine: Lessons from Native American healing. New York: Fireside Press (1997); Peat, F.D. Lighting the seventh fire: The spiritual ways, healing and science of the Native American. New York: Birch Lane Press, (1995); Suzuki, D. The sacred balance: Rediscovering our place in nature. Toronto: Greystone Books (1997); McCabe Glen, Mind, body, emotions and spirit: reaching to the ancestors for healing, Counselling Psychology Quarterly Vol. 21, No. 2, 143-152 (June, 2008)). Western cultures for about the last thousand years, and particularly in the last five hundred years or so, have not been comfortable with this idea. They have tended to rely on the modern scientific model as developed by people like Galileo, Copernicus, and growing host of others since then, for trying to understand the nature of the cosmos and us in it (Peat, F.D. Lighting the seventh fire: The spiritual ways, healing and science of the Native American. New York: Birch Lane Press( 1995). Western science emphasizes that only evidence-based concrete models for explaining and understanding the world are acceptable (Suzuki (1997). Indigenous cultures have tended to adopt a mind, body, emotions and spirit dialogue. And for my part I have found this perspective extraordinary and surprisingly effective, and I keep thinking about it. ${ }^{26}$ The article does not discuss the Aristotle's taxonomy of justice in the Nicomachean Ethics, three kinds of justice distributive justice, rectificatory or corrective or commutative justice, and reciprocal justice - and the difference between natural justice and conventional justice and uses the term "Conventional" in the sense of Nagarjuna and Carlo Rovelli. Using it in that way it does not distinguish between the naturally just and the conventionally just. Instead of the idea that Justice represents some kind of juridical standard (see for ex: http://the-stewardship.org/standard.htm ), the author insists that it concerns inter alia the intrinsic ethicallspiritual mindful demand on judges.
} 
perspectives, but it does not make sense to look for its ultimate substratum. It does not make sense to look for its first substratum, also, if Prigogine ${ }^{27}$ is true that it is not possible to know with complete certainty the initial starting conditions for a system. ${ }^{28}$ This truth is as scientific as it is philosophical, political and legal, and it unfolds with unexpected nuance in this article.

If somebody says that now Civil Justice is exercised in every case on the compensation for nonmaterial damages (for ex), we could answer: It has no existence. The main issue of this article is: what does conventional existence of Civil Justice depend on?

Here we can confirm that it doesn't depend only upon Law and Judicial Reforms.

We are going to use the Complex Thinking ${ }^{29}$ concept where "the goal of method research is not to find a unitary principle of all knowledge, but to indicate the emergence of a complex thought, which cannot be reduced either to science or to philosophy, but which allows their intercommunication by operating dialogic loops". ${ }^{30}$

\section{Does conventional existence of Civil Justice depend upon political regime (democracy, totalitarianism, authoritarianism, hybrid or semi-authoritarian regimes ${ }^{31}$ )?}

\section{Is a political regime a requirement of justice or an instrument for realizing it?}

Together with democracy we take political settings which are substantially authoritarian though not without a significant component of pluralism and contestation. In large parts of the non-Western world, the amount of semi-authoritarian countries exceeds that of democracies. ${ }^{32}$ This is often reviewed as being part of a larger process of democratic failure. ${ }^{33}$

As the example of the second political setting the article refers to Russia, possibly the most influential and geopolitically grave semi-authoritarian state, but also aspires to contribute to discussions about Civil Justice in democratic and undemocratic contexts in general.

In the fast "swelling" scholarly research on authoritarianism the issue of the conventional existence of Civil Justice there has remained almost absent. Most reviews of semi-authoritarian regimes conduce to be couched in dichotomous terms as conflict or contradiction between power and society. We do not a priori refuse this elucidation, but we believe that it is a simplification, and we raise it for discussion.

\footnotetext{
${ }^{27}$ Ilya Prigogine (1917-2003) was a Belgian physical chemist who won the Nobel prize in 1977 for investigating the irreversibility of processes in complex physical systems that are far from equilibrium conditions. Prigogine's theory of dissipative structures applies to open systems that exchange energy with the environment. As systems become increasingly complex, they require more and more energy to maintain their structure. Complex systems are highly unstable and this gives rise to internal fluctuations within the system. A slight perturbation can drive the system into a sudden nonlinear change, where the new stability is even more coherent. This higher order is even more sensitive to perturbations. Internal fluctuations can force the system to even greater complexity. At each level of complexity, there is greater potential for new organization and change.

${ }_{28} \mathrm{https} / / /$ www.statpac.org/walonick/reality.htm

${ }^{29}$ A philosophical concept created by Henri Laborit and introduced by Edgar Morin. Edgar Morin (8 July 1921) is a French philosopher and sociologist who has been internationally recognized for his work on complexity and "complex thought" (pensée complexe) and for his scholarly contributions to such diverse fields as media studies, politics, sociology, visual anthropology, ecology, education, and systems biology. He holds degrees in history, economics, and law.

${ }^{30}$ The formulation of Complex Thought is from: Morin Edgar, Science avec conscience (1982).

${ }^{31}$ The debate on "hybrid" political regimes is arguably one of the most essential modern events in comparative politics. The phenomenon of hybrid or semi-authoritarian regimes is linked to post-Cold War political development, and connects with regimes that democratized only parcel or that went through processes of regression after incipient democratic change, ultimately uniting aspects of democracy and authoritarianism (Diamond Larry Jay, Thinking About Hybrid Regimes, Journal of Democracy, Volume 13, Number 2, 21-35 (April 2002); Levitsky Steven, Way Lucan A, Competitive Authoritarianism. Hybrid Regimes after the Cold War, Cambridge University Press (2010)).

${ }^{32}$ Levitsky and Way, 2010, discuss 35 semi- or competitive authoritarian regimes from Latin America, Europe and Asia.

${ }^{33}$ See Huntington, Samuel P. The Third Wave: Democratization in the Late Twentieth Century, University of Oklahoma Press (1993) for earlier processes of democratic regression; see further: Diamond, Larry J. The Spirit of Democracy. The Struggle to Build Free Societies Throughout the World. New York, Times Books (2008).
} 
This also relates to the link between the civil justice's conventional existence and political stability or change.

The main question of the scientific discussion about hybrids is whether to consider them as a transitional form on the path to stable democracy or authoritarianism, or as an independent stable type of political system. So far, observations show that the hybrids are quite stable, but at the same time unstable. Semi-authoritarian regimes are weighed to be more elusive than either democracies or full dictatorships. ${ }^{34}$ Instability normally follows from the intrinsically conflicting nature of these regimes: the mixture of authoritarian practices with principally democratic institutions and procedures. "Authoritarian regimes may coexist indefinitely with significant democratic institutions", Levitsky and Way $(2002,58)$ debate, but "the coexistence of democratic rules and autocratic methods (...) creates an inherent source of instability". The tension between institutions and identities may nowhere be more undisguised - the "democratic" features of Civil Justice, designed to achieve it, may actually weaken and undermine it. In other words, hybrids are not destroyed as a result of a coup or external aggression, like totalitarian and authoritarian regimes, but they are slowly reborn - either into a democracy, or into an autocracy, or into a failed state (they fall into chaos and lose territorial integrity). Political scientist E. Shulman says that the first scenario is the most frequent - over time, hybrids tend to become, albeit weak and flawed, democracies. The second and third scenarios are driven by the same factors. This means that the regime has only two options: either becomes a democracy, or becomes autocratic and / or falls apart. Generally, three factors influence the fate of a hybrid regime, says E. Shulman:

- The number of democratic institutions that the regime imitates. No matter how decorative they are, the more a regime pretends to be a democracy, the more chances it has of gradually becoming one. Therefore, legislative changes in any direction are never a "formality", but an important sign of regime transformation;

- The degree of integration into international political and economic structures - the more the regime is isolated, the sooner it becomes autocracy or disintegrates;

- The presence of a large external trade and political partner. If it is a democracy (for example, the US or the EU), the regime will move towards democracy. If it is autocratic (e.g. China), the regime will drift towards autocracy, or disintegrate. ${ }^{35}$

In Russia and in an incremental number of other countries, democracy is not simply being superseded by politically completed authoritarian rule. Traits of democracy and authoritarianism are being intermixed. They correspond, even though apprehensively. Scholars struggle with the conceptualization of these essentially novel political trajectories that have imitated various characteristics of democracy, but which act in a definitely non-democratic way. Our questions are: Is the justice achievable solo in a democratic country? Does the other political regime deal with injustice, a priori? Or a political regime isn't a requirement of justice or an instrument for realizing it, is it..?

The authoritarian trajectory in Russian politics from the mid-1990s is assuredly parallel with the political directions in other countries that were once part of the "third wave of democratization". ${ }^{36}$ In 2005-2006, Deputy Head of the Presidential Administration of Russia V. Surkov invented the political concept of Sovereign Democracy. ${ }^{37}$ According to Surkov, sovereign democracy is: A society's political life where the political powers, their authorities and decisions are decided and controlled by a diverse Russian nation for the purpose of reaching material welfare, freedom and fairness by all citizens, social groups and nationalities, by the people that formed it.

\footnotetext{
${ }^{34}$ Brownlee Jason, Authoritarianism in an Age of Democratization, Cambridge University Press (2007); Huntington Samuel P, The Third Wave: Democratization in the Late 20th Century (1993); Levitsky and Way, Competitive Authoritarianism: The Origins and Dynamics of Hybrid Regimes in the Post-Cold War Era (2002)

${ }^{35} \mathrm{https}: / /$ meduza.io/cards/kakoy-v-rossii-politicheskiy-rezhim

${ }^{36}$ Huntington, Samuel P. The Third Wave: Democratization in the Late Twentieth Century, University of Oklahoma Press (1993)

${ }^{37}$ The term was first used by Vladislav Surkov on 22 February 2006 in a speech before a gathering of the Russian political party United Russia.
} 
This term was used thereafter by political figures such as Sergei Ivanov, Vladimir Putin, Boris Gryzlov and Vasily Yakemenko. It was the official ideology of the Russian youth movement NASHI, created in support of Vladimir Putin.

Sovereign democracy was devised as the quintessential Russian alternate to the allegedly general (Western) idea of liberal democracy. ${ }^{38}$ It was one of the main ideologemes in the Duma and presidential elections in Russia in 2007-2008. Sovereign Democracy in Russia was realised in the form of a dominant-party system which was put into place in 2007 when as a result of the Russian legislative election of 2007 the political party United Russia, headed by president Vladimir Putin, without forming a government, formally became the leading and guiding force in Russian society. ${ }^{39}$ While sovereign democracy did not evolve into a fully cherished national Weltanschauung (ideology) of Russian Federation, its underlying thoughts and reasoning were of great sense for Russia's self-perception (and the policies arising from it) and for how the country is viewed by others now.

Some modern scholars attribute Russia to a political system that is democratic in form, and to a political regime that is distinguished by Russian originality associated with a personal factor. This feature predetermined the creation of various political regimes of Boris Yeltsin and Vladimir Putin. $^{40}$

Berkeley professor Stephen Fish describes Putinism ${ }^{41}$ as a form of conservative, populist and personalist autocracy, which he calls a form of autocracy. ${ }^{42}$

V. Nikonov writes: "by "Putinism" I mean the current Russian regime and the ideology of President Vladimir Putin. Disclosure of the topic involves not only an answer to the sacramental question:

"Who is Mr. Putin?", But also the definition of what country we live in now, under what system.

What do we have in our yard - democracy, authoritarianism, totalitarianism? What is the ratio of the various branches of government?",43

"What is Putinism? Much intellectual energy has been devoted to finding a precise definition, as it so often happens when a new regime emerges. But it was not a very successful venture: Putinism is state capitalism, liberal economic policies, but also strong state intervention - even almost total intervention when important issues are raised. It is autocracy, but nothing new in Russian history, and almost mitigated by inefficiency and corruption. There is parliament, but opposition parties are not really in opposition. There is a free press, but freedom is limited to small newspapers, and criticism should not go too far. There is a constitution, but this is not the best guide to the realities of modern Russia."- Walter Laqueur writes. ${ }^{44}$

In February 2019, Vladislav Surkov proposed the ideology of "Putin's long state", which updated and urged to study Putinism as the "ideology of everyday life" of the future.

M. Krasnov sees the preconditions for a personalist regime in the RF Constitution. ${ }^{45}$

On January 15, 2020, in his State of the Union speech, Russian President Vladimir Putin presented his proposals for comprehensive changes in the Russian Constitution. On January 20, Putin

\footnotetext{
${ }^{38}$ Okara Andrei, Sovereign Democracy: A New Russian Idea or a PR Project? Russia in Global Affairs,3 (2008);

Polyakov, Leonid (ed.), Pro Suverennuyu Demokratiyu. (Sovereign Democracy) Moscow: Izdatel'stvo Evropa (2007);

Surkov Vladislav, Natsionalizatsiya Budushchego. Paragrafy pro Suverennuyu Demokratiyu, Ekspert, 43 (2006)

${ }^{39}$ Concrete priorities and orientations of Sovereign Democracy were conceptualized in Prime Minister Putin's Plan.

${ }^{40} \mathrm{https}: / /$ lib.herzen.spb.ru/media/magazines/contents/1/8(35)/baranov_8_35_54_64.pdf

${ }^{41}$ The first mentions of Putinism are of a journalistic nature; in Russia it first appeared on the Yabloko party's website in 2000, but became widespread after the article of William Safir for the New York Times: WILLIAM SAFIREJAN, Essay; Putinism Looms By. 31 (2000), https:/www.nytimes.com/2000/01/31/opinion/essay-putinism-looms.html The term Putinism was introduced into scientific use by the political scientist Vyacheslav Nikonov in 2003 as a political system that was established in Russia after Vladimir Putin came to power in 2000, and its ideology (Nikonov V. Putinism // Modern Russian politics: A course of lectures / Ed. V. Nikonov. International University (Moscow), OLMA Media Group (2003)

${ }^{42}$ Fish, M. Steven, The Kremlin Emboldened: What Is Putinism? Journal of Democracy, 28, 4, 61-75 (2017)

${ }^{43}$ Nikonov V. Opt. Cit, 29.

${ }^{44}$ Laqueur, Walter, Putinism: Russia and Its Future with the West. - New York: Thomas Dunne Books (2015)

${ }^{45}$ Krasnov, M. A. Personalist regime in Russia: experience of institutional analysis. M.: Foundation "Liberal Mission" (2006).
} 
submitted draft amendments to the State Duma, the lower house of the Russian federal legislature. In the course of several weeks, the initial draft underwent significant alterations, was approved by both houses of the Russian parliament in early March, and was signed into law by Putin on March 14. In mid-March, the Constitutional Court of Russia examined the issue of constitutionality of the presidential amendments and found them to conform to the Russian Constitution. On July 4, constitutional amendments entered into force after the electorate's approval in the course of the "nationwide vote."

During almost 27 years after its adoption in 1993, Russian Constitution has never seen such fundamental changes. Amendments to the Russian Constitution that came into force on July, 2020, introduced unprecedented changes to the country's Basic Law.

Inter alia, the Russian Constitution (article 15(4)) mandates that international treaties to which Russia is a party form "an integral part of its legal system" and, in case of divergence, have precedence over national law. However, the new amendments adopted by the Russian Parliament and signed into law by President Vladimir Putin in March 2020, introduced into Article 79 a provision stipulating that "decisions of interstate bodies" shall not be "subject to enforcement in the Russian Federation" if they run counter to the Constitution.

The constitutional amendments also give the President power to nominate candidates for top national judge positions including those of the Constitutional Court, and to appoint all judges of federal courts and initiate their dismissal.

According to the 19 June 2020's opinion of Venice Commission, an advisory body of the Council of Europe, the amendments to Russian constitution would allow the Russian authorities to reject binding rulings by the European Court of Human Rights (ECtHR). Marie Struthers, Amnesty International's Eastern Europe and Central Asia Director, said:

"These constitutional amendments are an attempt by the Russian authorities to empower themselves to override ECtHR rulings. This is a blatant affront to human rights and the rule of law, and would rob many in Russia of a crucial avenue for justice.

"Everyone in Russia needs to understand that these and other wider amendments are another attack on the independence of the Russian judiciary and on the ECtHR."

The Venice Commission noted that Russia "made the political decision to join the Council of Europe and remain a member of the organisation. In ratifying the ECHR and accepting the jurisdiction of the Strasbourg Court, it has committed itself to executing the judgments of the Court". 46

Scholars agree that constitutional rights and freedoms of the Russian people are now in jeopardy because the new amendments are highly questionable since they are in breach of the fundamental principle that judges should be independent from other branches of power.

Some Russian legal practitioners concur with scholars in their criticism of this amendment. ${ }^{47}$ Some have the controversal opinion. "The amendment prohibiting the execution of international treaties if they contradict the Constitution of the Russian Federation will not affect relations between Russia and the European Court of Human Rights (ECtHR)", the lawyer Yevgeny Rubinstein says .

"Amendment to Art. 79 of the Constitution of the Russian Federation can hardly lead to a decrease in the number of complaints filed by Russian citizens or their lawyers to the ECHR. "

"Securing in the Constitution the provision on non-execution of decisions of interstate bodies in case of their contradiction with the Constitution of the Russian Federation is a legal and technical point - the provision migrated from the decision of the Constitutional Court of the Russian Federation to the Constitution of the Russian Federation. The procedure for the implementation of this provision is provided for by the aforementioned resolution. Therefore, such an amendment cannot have any meaningful impact on the relationship with the ECtHR. In fairness, it should be noted that such provisions are enshrined in the constitutions of some European countries, for

\footnotetext{
${ }^{46} \mathrm{https} / / / \mathrm{www}$.venice.coe.int/webforms/documents/default.aspx?pdffile=CDL-AD(2020)009-e

${ }^{47} \mathrm{https}: / /$ imrussia.org/en/analysis/3147-how-putin\%E2\%80\%99s-constitutional-amendments-affect-the-judiciary
} 
example, in Germany. And, as far as we know, such a rule did not limit either the right to appeal to the ECtHR, or the relationship with the ECtHR, "Evgeny Rubinstein added . ${ }^{48}$

Whereas Putin's constitutional amendments introduce significant modifications to all branches of power, we focus on the impact these amendments will have on the justice in Russia. Does the justice in Russia depend upon them?

But precisely to achieve justice what are the general solutions available to any country independently from its political settings? Could we offer the receipt, suitable for any nation, any state?

We pay attention to Civil Justice's democratic tools which operate under different conditions, including the semi-authoritarianism. The thought of adding qualifying adjectives to "authoritarianism" 49 is to betoken that these trajectories in politics employ political eloquence, establishments, and procedures which are not typically coupled with authoritarianism, but with democracy in the main. We start from the point that these "democratic" features are not a "facade building" ceremony, simply and solely. ${ }^{50}$ They can fit various aims: a guiding function (to rule more efficaciously), a declarative role, and /or a legitimizing one.

In this article we make a differentiation between institutional and ideational magnitudes of Civil Justice. The institutional approach to Civil Justice questions the relevance of the "democratic" provisions of Civil Justice in a semi-authoritarian setting, while the ideational measurement inquires for the thoughts and reasoning which affect, navigate and corroborate the Civil Justice.

In this setting the idea of mindfulness (consciousness) may be relevant. This idea runs all through the article. Supporting meta-perspectives on mindfulness, we aim to propose a more integral way of Civil Justice's achievement in modern world. We would like to debate conventional existence of Civil Justice on the basis of Ivan Ilyin's concept of consciousness of law. ${ }^{51}$ Besides, we intend to test does the concept of Ivan Ilyin show multiple parallels to and compatibilities with wellestablished legal doctrines and dogmas or not?

\section{The institutional approach (“democratic” provisions of Civil Justice)}

Democracy is associated with the Greeks and Romans who were also considered the founders of Western Civilization. The proverbial term "rule by the people" was coined by them.

There are different studies of Justice and Democracy in social sciences. ${ }^{52}$ Most scholars conclude that theories of justice designed for our world should be centrally concerned with democracy. ${ }^{53}$ In

\footnotetext{
${ }^{48}$ Source - "RIA Novosti", https://fparf.ru/news/media/popravka-v-st-79-konstitutsii-rf-ne-snizit-chislo-zhalobrossiyan-v-espch/

${ }^{49}$ Authoritarianism with adjectives is as extensively utilized today as democracy with adjectives (Collier, David and Levitsky Steven, Democracy with Adjectives: Conceptual Innovation in Comparative Research, World Politics, 49 (April), 430-451 (1997)) before. Russia and other countries have been tagged as "electoral" (Schedler Andreas, Electoral Authoritarianism: The Dynamics of Unfree Competition. London, Lynne Rynner (2006)), "plebiscitarian" (Rose, Richard et al., Russia Transformed: Developing Popular Support for a New Regime. New York, Cambridge University Press. (2006)), and more generally "competitive" authoritarian (Levitsky and Way, 2010).

${ }^{50}$ Some researchers analyzing hybrid regimes pay attention to the decorative nature of democratic institutions. See: Schulmann, Ekaterina. Царство политической имитации (The kingdom of political imitation), vedomosti.ru. https://www.vedomosti.ru/opinion/articles/2014/08/15/carstvo-imitacii

${ }^{51}$ Ivan Alexandrovich llyin (1883-1954) is Russian philosopher and legal scholar. Although forbidden under the Soviet regime, Ilyin`s thoughts and works have come to be more and more appreciated over the last twenty years, especially since his earthly remains were re-interred in Russia in 2005. It is possible to say that he is the favourite Russian thinker of our times. Like all prophets, however, he was of course mainly ignored, unappreciated and even persecuted in his own times. Today, Ilyin is understood to be the voice of the faithful Russian emigration, a spiritual leader, a teacher, a prophet, a visionary preacher. His prophetic insights have been justified since the fall of Communism and the huge interest in his works there now. Ilyin, who died over half a century ago, is the prophet of the new Russia which is being born and which alone can give the contemporary world a viable future, providing that it is given time to grow to fruition in contemporary Russia. One of the problems he worked on was the question: what has eventually led Russia to the tragedy of the revolution?

${ }^{52}$ See in detail: Dowding Keith, Goodinand Robert E, Pateman Carol (eds), Justice and Democracy: Essays for Brian Barry, Cambridge: Cambridge University Press, (2004), Gould Carol, Globalizing Democrac and Human
} 
the book "Democratic Justice" Ian Shapiro shows how Democracy and Justice should be pursued together, why Justice must be sought democratically. ${ }^{54}$

Courts play an important role in democracy. A. Barak writes: Whether interpreting Constitution and other legislation, examining election outcomes, the legal status of terrorism suspects or if (or how) people can protect their rights and freedom, a judge in a modern democracy undertakes for a role that promotes some of the most contentious political issues of our day. ${ }^{55}$ Gibson, Calderia and Baird note the worldwide ubiquity of courts and judges involved in resolving disputes and answering questions with heavy policy implications. ${ }^{56}$ Shapiro and Stone state that "a political jurisprudence of rights is today endemic and occasionally epidemic". 57

There is also the idea that democracy and justice are mutually antagonistic things, the judicial power is undemocratic, which rests on a conception of democracy that means "the rule of majority". ${ }^{58}$ Benito and Andronova argue that in modern developed economies, wealth creation depends substantially on market exchange, which requires a legal environment capable of increasing the capacity of parties to define the wealth-enhancing terms of trade and to enforce their agreements. Courts fill in the gaps in the contract and the received set of rules, define the terms of exchange for all remaining unforeseen contingencies, and also provide last-resort enforcement of contractual agreements. ${ }^{59}$

Civil Justice (Factor 7 of the WJP Rule of Law Index) ${ }^{60}$ measures whether ordinary people can resolve their grievances peacefully and effectively through the civil justice system. The delivery of effective civil justice requires that the system should be accessible and affordable (7.1), free of discrimination (7.2), free of corruption (7.3), and without improper influence by public officials (7.4). The delivery of effective civil justice also necessitates that court proceedings are conducted in a timely manner and not subject to unreasonable delays (7.5). Finally, recognizing the value of Alternative Dispute Resolution mechanisms (ADRs), this factor also measures the accessibility, impartiality, and efficiency of mediation and arbitration systems that enable parties to resolve civil disputes (7.7).

Subfactors:

7.1 People can access and afford civil justice

7.2 Civil justice is free of discrimination

7.3 Civil justice is free of corruption

7.4 Civil justice is free of improper government influence

7.5 Civil justice is not subject to unreasonable delays

7.6 Civil justice is effectively enforced

7.7 ADRs are accessible, impartial, and effective. ${ }^{61}$

Democratic tools of Civil Justice concern chiefly law and society (Barak, 2006). For Barak ${ }^{62}$, the role of the judge in democracy is to understand the purpose of law in society, to help the law

Rights, Cambridge: Cambridge University Press (2004), Christiano Thomas, The Constitution of Equality, Oxford Oxford University Press (2008), The Authority of Democracy, Journal of Political Philosophy, 12 (3) (2004), 266-90.

${ }^{53}$ Valentini Laura, Justice and Democracy, The Queen's College, Oxford (CSSJ Working Papers Series, SJ012,

November 2010)

${ }^{54}$ Shapiro Ian, Democratic Justice, New Haven: Yale University Press (2001)

${ }_{55}^{55}$ Barak Aharon, The Judge in a Democracy (2006)

${ }^{56}$ Gibson J, Calderia G, Baird V. On the Legitimacy of High Courts, (1998), American Political Science Review, 92.

${ }_{58}^{57}$ Shapiro M, Stone A. The New Constitutional Politics in Europe, (1994), 26, Comparative Political Studies, 409.

${ }^{58}$ Russel P. Corry Lecture on Law and Politics. 1987, 12, Queen`s L.J. 421.

${ }^{59}$ Benito Arruñada, Andonova Veneta, Judges' Cognition and Market Order, Review of Law and Economics, 4(2), 66592, (2008); Benito Arruñada, Andonova Veneta, Market Institutions and Judicial Rulemaking, in Claude Ménard and Mary M. Shirley, eds., Handbook of New Institutional Economics, Dordrecht, Springer, 229-250 (2005)

${ }^{60}$ The World Justice Project Rule of Law Index ${ }^{\circledR}$ is the world's leading source for original, independent data on the rule of law. Covering 128 countries and jurisdictions, the Index relies on national surveys of more than 130,000 households and 4,000 legal practitioners and experts to measure how the rule of law is experienced and perceived worldwide, https://worldjusticeproject.org/our-work/research-and-data/wjp-rule-law-index-2019

${ }^{61} \mathrm{https}$ ://worldjusticeproject.org/our-work/wjp-rule-law-index/wjp-rule-law-index-2017\%E2\%80\%932018/factors-rulelaw/civil-justice-factor-7?page $=21$ 
achieve its purpose, to protect Constitution and democracy. For Franklin and Kosaki courts are originally intended to be "republican schoolmasters," teaching the public to support the rights and liberties of their fellow citizens. ${ }^{63}$ Benito and Andronova argue that judicial activity in west European countries deals with protection of freedom of contract and developing the market order. For Benito and Andronova the proper functioning of a market economy requires that freedom of contract be protected effectively (Benito\&Andronova, 29). This can be achieved in different ways in democracy. A major design decision concerns the role that the legislator delegates to courts. Reforming the justice sector and improving people's capacity to access justice go hand-in-hand with enforcing the rule of law.

The Rule of Law is considered to be a necessary condition for the development of a successful democracy. ${ }^{64}$ For a state to be called a "rule of law state" (or "Rechtsstaat"), certain basic elements and institutions must be in place. Among these are: Separation of Powers; Legality of Administration, in particular the Principle of Legal Certainty and Unity, part of which are, inter alia, the Principle of Reliability, the Prohibition of Retroactive Acts, and the Principle of Proportionality; The Guarantee of Fundamental Rights and Freedoms and Equality before the Law. The fundamental principles of the separation of powers and judicial independence are considered central tenets of all liberal democracies, everywhere and in every time. And rightly so.

With the words "there is no liberty, if the judiciary power be not separated from the legislative and executive" ${ }^{\prime 65}$ we can say: there is no conventional existence of civil justice if the judiciary power be not separated from the legislative and executive.

The tenet of the separation of powers is increasingly weighed to be the conditio sine qua non of a successful democracy. Grosso modo, under the chef d oeuvre of Montesquieu The Spirits of the Laws, disseminating the separation of powers doctrine, both the separation of organs and separation of functions (divide et impera) have emanated as the pillars of the concept of the separation of powers.

However, in Italy and many other democratic European countries contemporary political reality shows that the division of powers became even more liquid and sometimes bewildering especially in what refers to the legislative function firstly shared with some heed and disinclination with the executive branch and now captured by the judiciary ${ }^{66}$ including judicial discretion phenomenon (in spite of the lack of consensus about its definition ${ }^{67}$ ). It should be observed that the tenet of the separation of powers is not always well defined, often referring to related but different phenomena. Moreover, to a more careful consideration, the relationship between the state branches seems more complex than expected. The European scholars write that nowadays in continental Europe the judiciary is faced with opinion as constitutional and supreme courts are acting like legislators, creating the law of judges, sometimes with competition with the rule of law. ${ }^{68}$

The publications of A.Barak (2006) and R. Posner (2006) led to a great deal of public discussion about the judicial role in democracy. For Barak ${ }^{69}$, Gibson, Calderia and Baird ${ }^{70}$, the judge in a modern democracy undertakes for a role that promotes some of the most contentious political issues

\footnotetext{
${ }^{62}$ Barak, A, The judge in a Democracy, 3 (2006)

${ }^{63}$ Franklin Charles, and Liane C. Kosaki. Media, Knowledge, and Public Evaluations of the Supreme Court." In Contemplating Courts, ed. Lee Epstein. Washington, DC: Congressional Quarterly Books (1995).

${ }^{64}$ See, inter alia: Carothers T, Promoting the Rule of Law Abroad: In Search of Knowledge, Washington, Carnegie Endowment Press (2006); Morlino L. and Magen A, International Actors, Democratization and the Rule of Law, London, Routledge. (2008).

${ }^{65}$ Montesquieu Charles-Louis de Seconda, The Spirit of Laws, Book XI, 6 Of the Constitution of England (1748)

${ }^{66}$ Urbano M.B. The Law of Judges: Attempting Against Montesquieu Legacy or a New Configuration for an Old Principle? IIVIII World Congress of the International Association of Constitutional Law, Mexico (6-10 December 2010)

${ }^{67}$ See in detail: Hoffmaster Barry, Understanding Judicial Discretion, https://www.jstor.org/stable/3504779?seq=1

${ }^{68}$ See, example gratia: Interpreting precedents: A comparative study / Ed. by D. Neil MacCormick, R.S. Summers Aldershot etc. (1997); Vereschagin A.N. Судебное правотворчество в России: сравнительно-правовые аспекты. M (2004); Marchenko M.N. Судебное правотворчество и судейское право. М. (2007).

${ }^{69}$ Barak Aharon, The Judge in a Democracy, Princeton (2006)

${ }^{70}$ Gibson J, Calderia G, Baird V. On the Legitimacy of High Courts, American Political Science Review, 92 (1998).
} 
of our day (Barak, 2006). Shapiro and Stone state that "a political jurisprudence of rights is today endemic and occasionally epidemic". ${ }^{71}$ For Posner, judges are political actors and (sometimes) legislators who are motivated by the dual desires of making the world a better place and of playing the "judicial game". ${ }^{72}$ Professor E. Chemerinsky writes that judges make law constantly, and in doing so they draw on their judgment, which is based on their ideology and experiences. ${ }^{73}$ Professor W. Farnsworth concludes that once a case is close enough to create dissent, the source of law involved tends to diminish in importance; the decision ends up being made on the basis of policy judgments that cut across the divide between constitutional and non-constitutional sources of law. ${ }^{74}$ The next contribution comes from Michael Boudin. ${ }^{75}$ In his remarks, Boudin agrees that the actual work of judges today is quite different from their historical roles of resolving criminal and civil disputes. Judges are indeed lawmakers, but, Boudin cautions, this role can only remain beneficial and secure if it is employed with due regard for the legislature. When courts act as reformers and effect dramatic innovation, they set themselves up against the democratic process and invite a backlash. ${ }^{76}$ Although Barak, Posner, Chemerinsky, Farnsworth, Boudin and others address the ageold dispute over whether judges must interpret and not "make" law, this article demonstrates that this question cannot be answered in the abstract, especially these days.

The central premise of this paper is that the twenty-first century presents new challenges to the judiciary - challenges which may sometimes leave existing law and procedure in a kind of limbo. Human cloning, computer data mining, and computer-generated judicial profiles, etc on one side, and the era of globalization, terror, new diseases (Covid-19 etc) on another side, are obvious examples. Scholars ' pragmatism, with its emphasis on "what works," might fill the legal void when new challenges arise. But precisely what are the general solutions available to the law maker and the judiciary? Could we offer the receipt, suitable for any nation, any state?

The topic is itself moving target. Over the next decades, judges will be required to apply laws to radically different circumstances as a result of a new era we can only begin to imagine. Global threats, political, environmental, epidemic, will put immense stress on the institution of the judiciary. The unpredictable and unprecedented nature of such developments makes all analyses of the conventional existence of Civil Justice highly provisional, but also necessary, and as it turned out, highly stimulating. General theory, common for democratic and nondemocratic countries, is needed to be developed. The Eastern and Central European states can provide important insights in the matter, thanks to their relative common institutional development: a long period of communist rule and a transition to democracy.

Let us start from the definition of the separation of powers. We hypothesize that it does not follow from the verbal design of "the separation of powers" that law can't be embodied in judicial decisions.

Before going further, some clarification must be made about the issue at stake. As the concept of the separation of powers is not solid we would like to note that for the purpose of this paper the term of the separation of powers is used as the legal principle of a state machinery`s organization. This principle is looked as an organizational, a legal, an institutional component of the rule of law state. It is implemented in the developed state-legal situation. The difference between the branches according to their competences is peculiar to the undeveloped state-legal situation, also, but there their separation is absent and the state machinery is designed under the principle of organizational unity. Namely under such conditions political- legal consciousness regards the "state will" as the creative force, the material source of law. A contrario, both the developed legal situation and the

\footnotetext{
${ }^{71}$ Shapiro M, Stone A. The New Constitutional Politics in Europe, 26, Comparative Political Studies, 409 (1994)

${ }^{72}$ Posner Richard A., The Role of the Judge in the Twenty-First Century, 86 B.U. L. REV. 1049, 1063 (2006)

${ }^{73}$ Chemerinsky Erwin, Seeing the Emperor's Clothes: Recognizing the Reality of Constitutional Decision Making, 86 B.U. L. REV. 1069 (2006).

${ }^{74}$ Farnsworth Ward, The Role of Law in Close Cases: Some Evidence from the Federal Courts of Appeals, 86 B.U. L. REV. 1083 (2006).

${ }_{75}$ Boudin Michael, The Real Roles of Judges, 86 B.U. L. REV. 1097 (2006).

${ }^{76}$ Id. at 1098
} 
separation of powers mean free political competition. Consequently, the single "state will", shaping law, is entirely absent. Example gratia, one of the predominant features of the parliamentary politics can be the tendency to the restraint of legal freedom by the privileges of one or another social group. According to its constitutional competency the judicial power, ex officio, can counteract to this tendency and to pronounce the decision of illegality of parliamentary acts, breaching equal rights, formal equality, etc. ${ }^{77}$

First and foremost the separation of powers signifies the spread of the state authority "across" to prevent tyranny and to pave the way for judicial discretion, accordingly. And the matter is not only that the executive power (and the judicial power) can't be realized without regard for any competence, formulated by the legislative power, but also that the legislative power itself is controlled by the judicial power apropos of compliance of the laws with fundamental legal principles. So, famous Edward Coke maintained that neither Parliament, nor a parliamentary act could cancel the legal principles, upon which law was designed. ${ }^{78}$

In this context illustrious Friedrich August von Hayek ${ }^{79}$ wrote that the freedom of Britons was not the result of the separation of powers as Montesquieu taught and Brits themselves believed. It was the consequence of the fact that judicial decisions were guided by the common law, which was irrespective of anyone`s will and was formulated by independent judges, at the same time. And on rare occasions the Parliament interfered in that process with the object of law`s clarification. Friedrich August von Hayek asserted that the separation of powers originated in England not only because the legislative power created statutes, and therefore that it did not do that: the sources of law were formed by courts, independent from that power, which organized and directed the government and was called "legislative" by mistake. ${ }^{80}$

It is interesting that the classical common law doctrine ${ }^{81}$ of XVII-XVIII centuries took notice of the necessity to follow the precedents` rules to avoid free judicial discretion.

In the general flow of the "free judicial discretion", there were various streams. Some scientists, for example Professor Shtampe, categorically rejected the provision on the subordination of the judiciary and recognized the right of the courts to act contra legem. Other scholars (G. Kantorovich, $\mathrm{V}$. Berngen) defended the free judicial discretion sine lege: they recognized it only in cases stipulated by law. ${ }^{82}$

Everyone should be bound by the rules of res judicata. The doctrine saw the main difference between the judicial and the legislative powers in that fact, exactly. ${ }^{83}$ It was supposed that naturally

\footnotetext{
${ }^{77}$ So, in the USA (in contrast to the European states) during more than 30 years of XX century labor relations were regulating under the principle of formal equality, and the principle of contract freedom in the labor sector was prevailing. The USA Supreme Court (1905) decided that the Constitution did not permit the meddling of a state in the right of a worker to enter into an employment contract freely (Locher v.New York). The legislature of a state did not have the right to deprive the worker of a work on the ground of bad terms of the contract. The right of the worker to enter into such labor contract, as he agreed to conclude, was declared as fundamental and constitutional. Only in 1937 (West Coast Hotel v. Parrich) the USA Supreme Court cancelled the decision Locher v. New York and established that the state had the right to regulate the employment relations between the worker and an employer (see in details: Osakve K. Сравнительное правоведение в схемах. М, 51 (2000).

${ }^{78}$ Dr. Bonham case (1610) 8 Co Rep. 118a (Coke E. Part Nine of the Reports // The selected writings and speeches of Sir Edward Coke. Vol. 1 / Edited by Steve Sheppard. Indianapolis (2003).

${ }^{79}$ See in detail: Sola Juan Vicente, Hayek the Rule of Law and the Challenge of Emergency.

${ }^{80}$ Hayek Friedrich August. Право, законодательство и свобода: Современное понимание либеральных принципов справедливости и политики / Translation from English, ed. Kurjaev. M., 104 (2006)

${ }^{81}$ See about the fundamental differences between the common-law and civil-law systems and their distinct approaches to the law in: John H. Merryman \& David S. Clark, Comparative Law: Western European and Latin American Legal Systems 213 (1978); Woodfin L. Butte, Stare Decisis, Doctrine, and Jurisprudence in Mexico and Elsewhere, in The Role of Judicial Decisions and Doctrine in Civil Law and in Mixed Jurisdictions 315 (Joseph Dainow ed. 1974).

${ }^{82}$ Pokrovsky I.A. The main problems of civil law, http://civil.consultant.ru/elib/books/23/page_12.html Iossif A Pokrovsky (Russian Иосиф Алексеевич Покровский;1868 -1920) was a legal scholar of the Russian Empire, which is still considered a great classic of civil law in Russia.

${ }^{83}$ Vereschagin A.N. Opt.cit, 318-319.
} 
parliamentary acts could be examined as free decisions, expressing the opinion of one or another majority, while judicial acts should be just legal decisions and its principles could not be canceled or changed by any majority.

In other words, the tenet of the separation of powers implied that, firstly, law could be only judicial law and, secondly, there was a danger that courts would exercise law-making ("law-speaking") arbitrary, but the doctrine opposed namely that fact (summum jus - summa injuria). According to the tenet, the law-making was a fate of those who knew and applied law and not those who had a power to govern (that was a legal paradigm). But in one`s turn the judicial activism should obey the rules of law, without fail. In this sense the common law doctrine is not opposite to the famous warning of Montesquieu that if the judicial power is connected with the legislative power, the judge can become an oppressor. ${ }^{84}$ The forensic law-making should not create the situation when the judge conducts and resolves a case according to the rules that he establishes by himself and changes according to his discretion. The classical doctrine insisted on the fact that the common law consisted of not separate components, but of common principles, that were concretized, explained and illustrated by precedents (res judicata). This means that the common law judge "should know how to retrieve universal meaningful rules, which can be applied to a new litigation, from suitable precedents." 85

So, under the common law the original separation of powers did not deny the judicial law-making as well as did not suppose that the Parliamentary authority was the law-making power.

Identification of the Parliamentary legislatio with the law-making is the credit of the continental legal tenant (version of XIX century). Does this position of the continental doctrine correspond to the principle of the separation of powers?

The attempt to disclaim the judicial law-making by reason of the separation of powers is the evidence of some mechanical interpretation of the tenant: the legislator establishes the rule of law, the judge is "merely mouthpiece of the law"; law is just the statute, the judicial power strictly applies the laws. This interpretation means not the separation of powers, but the separation of work within the model of organizational unity of the state power: there is the supremacy of the legislator de jure, but de facto there is the absolute position of a political person who directs and controls the nominal legislator. The separation of the legislative and the judicial powers does mean some judicial independence in relation to the legislator and the law.

Following the classical ethos of liberal constitutionalism, independent judges are reckoned to be the indispensable implement in order to enforce the law in a consistent and impartial way. However, there are different approaches to the definition of independent justice and its relation to the doctrine of the separation of powers.

The definitions suggesting by international organizations heavily lay stress the necessity of the judicial power`s isolation from external - and especially political - influence of other branches. For instance, under the U.N. Basic Principles on the Independence of the Judiciary enacted in 1985, "The judiciary shall decide matters before them impartially, on the basis of facts and in accordance with the law, without any restrictions, improper influences, inducements, pressures, threats or interferences, direct or indirect, from any quarter or for any reason." (Principle n.2, italics added). ${ }^{86}$ In Europe, the growth of a policy discourse on the rule of law and independent justice has been realized by the Council of Europe, to a large extent. As for judicial independence, in 1994 the Council of Europe issued a Recommendation establishing, inter alia, that "in the decision-making process, judges should be independent and be able to act without any restriction, improper

\footnotetext{
${ }^{84}$ See in detail here: https://oll.libertyfund.org/pages/montesquieu-and-the-separation-of-powers

${ }_{86}^{85}$ Hayek Friedrich August. Opt.cit, 105.

https://www.ohchr.org/en/professionalinterest/pages/independencejudiciary.aspx\#: :text=The\%20judiciary $\% 20$ shall $\% 2$ 0decide\%20matters, quarter\%20or\%20for\%20any\%20reason.
} 
influence, inducements, pressures, threats or interferences, direct or indirect, from any quarter or for any reason." 87

However, scholars seem to be less optimistic on the virtues of independent justice. For instance, Professor Michael Gerhardt debates the sharply divergent views on whether Judicial Independence is a procedural or substantive value. ${ }^{88}$ Professor Sanford Levinson wants to know what we mean by the concept of "Judicial Independence." The problem in answering the question, he opines, is the difficulty of separating the debate from the politics surrounding it. ${ }^{89}$ According to Martin Shapiro, since no regime "is likely to allow significant political power to be wielded by an isolated judicial corps free of political restraints", ${ }^{90}$ independent justice is always bound. In fact, we "expect courts to be independent at retail, not wholesale... to make their decisions according to the law... to be... the servants of the lawmakers". ${ }^{91}$ P.H.Russell contests the attempts to insulate judges from their environment. $^{92}$

A modern essential contribution to the definition of the concept of independent justice and to the analysis of its place in the doctrine of the separation of powers has been generated by some scholars of Law and Economics. L. Feld and S.Voigt focus on highest courts and institute a difference between de jure and de facto independent justice. ${ }^{93}$ De jure indicator directs only at legal rules, the law, concerning the status of high court judges and their competencies and power. De facto indicator endeavours to grasp the empirical dimension of independent justice and deals with judicial power in practice. ${ }^{94}$ B.Hayo and S.Voigt maintained later that de facto independent justice is hard clarified by freedom of the press and, to a larger extent, by de jure independent justice. ${ }^{95}$ The significance of the distinction between internal and external independent justice is supported also by Rìos Figueroa. ${ }^{96}$

Virtually, the problem is: how is it possible to ascertain that a judge has "applied the law" or "created the law"? May it be to define the extent of judicial decisions " control which is not in contradiction with the independence of the judge and the judicial power? To what extent does the doctrine imply that the law - i.e. statutes - should be interpreted in the exactly the same way in all circumstances? We can refer here to the need of judges to follow "generally recognized" rules, although we should take into account that there will always be some diversity in the legal community on the meaning of some rules. We can also think that some degree of flexibility in the law`s interpretation is not in contradiction with the doctrine of the separation of powers and with the independent justice.

If the court is strictly bound by the law (as the school of legists maintains that rules of law identify with legislator's behests, only), there is not the separation of powers: if the court is "merely mouthpiece of the law", he can be just the legislator's "appendage", the statutes' executor. If the branches are separated, the court can't be bound by the law, totally.

\footnotetext{
${ }^{87}$ The text is similar to the UN Basic Principles. See: Independence, efficiency and role of the judges, Recommendation n. 12 (94), 2 d.

${ }^{88}$ Gerhardt J, What's Old Is New Again, 86 B.U. L. REV. 1267 (2006).

${ }^{89}$ Sanford Levinson, Identifying "Independence," 86 B.U. L. REV. 1297 -1299 (2006).

${ }^{90}$ Shapiro M. Courts. A Political and Comparative Analysis, Chicago, The University of Chicago Press, 34, (1981)

${ }^{91}$ Shapiro M. The European Court of Justice, in Russell and O’ Brien, 280 (2001)

${ }^{92}$ Russell P.H. Toward a General Theory of Judicial Independence, in P.H. Russell and D. O’Brien (eds.), Judicial Independence in the Age of Democracy. Charlottes ville: University Press of Virginia, 12, (2001)

${ }^{93}$ Feld L. and Voigt S, Economic Growth and Judicial Independence, in "European Journal of Political Economy, 19, 497-527 (2003)

${ }^{94}$ As it has been pointed out "the more discretion (and independence) judges have, the greater possibility that cases outcomes vary and law is applied inconsistently, counter the traditional conceptions of the rule of law."(Brashear Tiede, L. Positive Political Theory and the Law: Judicial Independence: Often Cited, Rarely Understood, in "The Journal of Contemporary Legal Issues", XV, 160 (2006).

${ }^{95}$ Hayo B. and Voigt S. Explaining de facto Judicial Independence, in "International Review of Law and Economics", 27, 269-290 (2007)

${ }^{96}$ Rìos-Figueroa, J. Judicial Independence: Definition, Measurement and Its Effects on Corruption. An Analysis of Latin America, Ph.D. Thesis, New York University, 163-164 (2006).
} 
Let us assume that legal regulation is exercised by the sovereign power, arbitrarily. Then it must be admitted that the statute, issued by the sovereign power, is the sole sourse of law, and courts should obey any change of the legislative policy, without demur. Such is the position of the court in the situation when the power is organized in according with the principle of organizational unity. Further let us concur, referring to the Roman legal maxim $a b$ abüsu ad usum non valet consequentia $^{97}$, that the legal regulation is not an arbitrary power and the legislation is complied with fundamental legal principles. Then there is no way to asset that only the legislator can utter these principles, properly. According to the doctrine of the separation of powers none of the legislator, the court, the administration possesses the monopoly to define law concerning either of relations, but each of branches should ensure legal freedom within its competency; inter alia, the court can`t issue statutes as Parliament, but he can recognize the laws as illegal and give such interpretation of the statute that mostly meets the principles of legal freedom. ${ }^{98}$

Both the judge and the lawmaker participate in the same process of legal regulation, but they use different means and fulfill dissimilar functions. ${ }^{99}$ Therefore the power, issuing the statutes, abstractly, and the power, resolving a case, and, in that way, formulating law on a pending suit, must be divided, organizationally and functionally. With that both powers are bound by the same fundamental principles of freedom, equality and equity to an identical extent ${ }^{100}$ and neither of them can pretend to the monopoly of its interpretation: so, the legislator "programmes" 101 the judicial system to construe law in definite way, but the competent courts (supreme and constitutional courts) can correct this "programme" if they conclude that the principles of law can be violated, otherwise. The court should not substitute for the legislator, tearing away his "law-speaking" from justice's tasks (inter alia, the court must not act as a super- legislator, an emperor) and the legislator can 't force independent judicial power to take either legal stand.

In the continental European legal tradition the content of law is not confined by the legislator's opinion. Beyond the legists ' doctrine it is considered that law in force, jus scriptum, is formulated by both the legislator, introducing the definite socio-political component into the process of lawmaking, and the judges, rather independent from politics. ${ }^{102}$ "Soviet authors, - Rene David wrote, blame judges of bourgeois countries for their independence in relation to the law. It is possible to doubt their interpretation but not just the fact. Judges of the Romanic-German legal family possess certain independence regarding the law, really, so law and the statute are not identified in these countries....the tradition ranks law higher than politics". ${ }^{103}$

The first attempt to openly address this problem within the framework of legislation was given by the Swiss Civil Code 1907. Its first article states that:

1. The law applies according to its wording or interpretation to all legal questions for which it contains a provision.

2. In the absence of a provision, the court shall decide in accordance with customary law and, in the absence of customary law, in accordance with the rule that it would make as legislator.

\footnotetext{
${ }^{97}$ It means 'a consequence from an abuse to a use is not valid.'

98 «The purpose of law (and the rule of law)...is the progress of freedom, equality and equity in the life of people... Responsiveness this proper legal aim (and legal value) of the rule of law, that have to be interpreted, defines the specific character of the teleological interpretation" (Nersesyanz V.S. Общая теория права и государства. 497).

${ }^{99}$ In this context Vereschagin A.N. writes about "the interaction between the legislative and the judicial ways of lawmaking, which should not contrast to each other, but should mean two different and mutually complementary stages of a single process, namely, the process of the legal regulation" (Vereschagin A.N. Opt.cit, 133-134)

${ }_{100}$ This point is reflected in the Constitution of Russian Federation. The article 18 maintains that human rights and freedoms tie together the all branches - "define the meaning, content, application of statutes, the functions of the legislative and executive powers, local government and are supplied with justice”. All Italian judges, as required by article 101 of Italian Constitution, are subject only to the law. Law is by definition unique, reliable and equal for all. The judges decide on the basis of the same normative texts.

${ }_{101}$ Zippelius R. Allgemeine Staatslehre (Politikwissenschaft). - 13., neubearb. Aufl. München, 317-318 (1999)

${ }_{102}$ Leoni B. Freedom and the law. Expanded 3d. edn. Indianapolis, (1991).

${ }_{103}$ David R., Jauffret-Spinosi C. Основные правовые системы современности / Translation from French by Tumanov V.A, M, 92-93 (1997).
} 
3. In doing so, the court shall follow established doctrine and case law.

Thus, the Swiss Code, completed the natural way of recognizing legal consciousness in a trial, securing a new stage of development: judicial discretion, based on the principles of expediency, can act in relation to the law supplendi causa. ${ }^{104}$

To mix law and the statute and to consider the statute as an exclusive source of law means to contradict the Romanic-German tradition. ${ }^{105}$

In Russia the doctrine exceeds the bounds of habitual dogmas of Soviet period, with reluctance. ${ }^{106}$ It seems that according to the democratic European legal tradition ${ }^{107}$ the doctrine of the separation of powers does not allow to maintain that acts of the judicial power can`t and must not be the sources of law. ${ }^{108}$

If it is consistent logically, the next opinion has to assert that only acts of the legislative power can be the sources of law pursuant to the separation of powers ( ad deliberandum $^{109}$ ). Not only judicial decisions but also acts of the executive power can't be the sources of law. Meanwhile the strictest separation of powers does not exclude the law-making activity of the executive power on the grounds of the law and to carry out the statute, inter alia, delegated legislation.

As per a subordinate regulatory act ${ }^{110}$, from the perspective of the separation of powers it is acceptable if a bylaw is considered as the authoritative interpretation of the law. The judicial power, applying jus strictum, possesses the competence to evaluate the correspondence of the bylaw to the statute. Any person, who believes that this authoritative interpretation violates his rights or freedoms, can care to go to law. Taking into account that legem brevem esse oportet ${ }^{111}$, namely the interpretative activity of the independent courts can lead to the correspondence of the "secondary legislation" to the "primary legislation": either the court recognizes the interpretation of the statute as a proper, preferable explanation, confirming the conformity of the subordinate regulatory act to the statute, or the court announces the bylaw as illegal and shows preference to another interpretation of the statute, imparting the official effect to it (scire leges non hoc est verba eârum tenēre, sed vim ac potestātem ${ }^{112}$ ).

Analogously, the Constitutional court, examining the constitutionality of the statute, either confirms legislative interpretation of the Constitutional provisions, and sometimes defines it more exactly by his regulatory interpretation, or recognizes it as contradictory to the Constitution and gives another interpretation of the Constitutional provisions.

\footnotetext{
${ }_{104}$ See about judicial discretion in detail: Papkova O.А. Усмотрение Суда. М, (2005).

${ }^{105}$ See about the benefits of different systems of legal adjudication and decision-making: Sir J Fortescue, De Laudibus Legum Angliae (In Praise of the Laws of England) (CUP 1825), defending the superior properties of English law compared to Roman law); Bentham J, 'Law as It Is', in Browning J (ed), The Works of Jeremy Bentham, vol.5 (William Tait 1843), criticizing the unpredictable and arbitrary character of decisions by common law judges); Weber M Economy and Society: An Outline of Interpretive Sociology, vol. 1 (University of California Press 1978), attributing the persistence of the common law in England to special interest pressure from lawyers' guilds, despite the "rational form of Roman law" and the "technically superior training of Roman-law jurists"; Hayek F, Law, Legislation and Liberty: ANew Statement of the Liberal Principles of Justice and Political Economy (Routledge \& Kegan 1973): "the ideal of individual liberty seems to have flourished chiefly among people where, at least for long periods, judge-made law predominated".

${ }^{106}$ Vereschagin A.N. Opt.cit, p. 31-32.

${ }^{107}$ It must be noted that the distinctions between the civil-law and common-law systems have blurred. Common-law countries are adopting some of the characteristics of the civil-law system, while civil-law countries are incorporating features of the common-law tradition into their legal systems. But significant differences remain and are likely to remain, as a result of the history and perceptions about the nature and purpose of law underlying each, one originating over 2,000 years ago and the other emerging in the twelfth century.

${ }^{108}$ See another position in: Nersesyanz V.S. Opt.cit, 351-353.

${ }^{109}$ For the purpose of deliberating

${ }^{110}$ Vereschagin A.N. Opt.cit, 137, 153

${ }^{111}$ The law needs to be concise

${ }^{112}$ To know the laws ls not to observe their mere words, but their force and power; (that is, the essential meaning in which their efficacy resides)
} 
At the same time there is an allegation that executive bodies (down to "any bodies and officials") possess the right to adopt subordinate regulatory acts, concretizing the provisions of the statute, even the statute does not allow such subordinate concretization. This assertion is of no convincingness. That follows from the doctrine of the separation of powers. ${ }^{113}$ It is obvious if the law does not assume such concretization, not the subordinate law-making (i.e. on the grounds of the law and to execute the law) but the illegal law-making (substitution for provisions of the law by opinions of "any bodies and officials" concerning what the law says, precisely) is expected. The court can 't take into consideration such "concretizing" acts, so he is under nothing but the Constitution and the law.

Et sic, there is no point in the dispute concerning the law-making power of the executive branch, as such, and the discussion can be devoted namely to limits of this power (example gratia, to the autonomous, preliminary or just concretizing rule-making of the executive branch) and to the place of the executive branch`s lawmaking acts in the system of sources of law.

In this case the opinion, not contradicting the law-making activity of the executive power for the separation of powers `reasons, but disclaiming the judicial law-making for the same reasons, is illogical.

Moreover, this opinion is denied by the fact that the precedent is the source of law (earlier it was the main source of law) in the common law countries, under the separation of powers conditions. Essentially, the opinion that in the civil law countries the precedent is not considered as the source of law, changes nothing. Even if it were not for the precedent, evaluating as the source of law under the continental legal doctrine, and if it had not been the same, the essence of the separation of powers would not be changed depending on the "legal geography". If in the common law countries the separation of powers does not impede the law-making activity of the supreme courts, in the civil law countries the separation of powers does not hinder from the judicial law-making, also.

Et sic, namely the separation of powers, understanding as the organizational and functional distribution of the state power, supposes that the judicial acts could be the sources of law. ${ }^{114}$ For, the separation of powers means, in particular, independent justice - independence of the judicial power in the course of "law-speaking" (competence) - in resolving cases" time, i.e. in ascertainment of law concerning a pending suit, interpretation of Constitution, statutes and other sources of law in the process of jurisdiction`s implementation. ${ }^{115}$

Hence it appears that the judicial law-making is feasible. It seems as an elegantia juris. The primary sources of law (creative precedents) and the secondary sources of law (precedents of interpretation, habits of judicial practice and even "quasi-normative" judicial acts - acts of normative interpretation) have resulted from that appearance.

From the perspective of the separation of powers, the judicial law-making is permissible just in the framework of forensic functions to resolve the case. The judicial power as represented by the

\footnotetext{
${ }^{113}$ So, Savizkiy V.A. and Terjukova E.U. write: «... the laws can be concretized, indeed, not only if it is set down by rules, but in any other case, when a body, possessing the right to accept subsidiary acts, considers such concretizing regulation as the necessity (if, of course, the strict ban to regulate one or another relation by a bylaw is absent). Basic limits of the law`s concretization by a bylaw is not defined (in principle, it can be set down by the law). Its absence allows to concretize the statute by anybody or official (not only by President`s and Government`s legal acts, but by acts of other bodies). Accessibility of such concretization without any special legal direction must be defined concerning a concrete case with due regard for the law`s subject and its place among other statutes, and proceeding from the need of law`s application" (Законодательный процесс / Ed. Vasiljev R.F. M. 49-50 (2000) [the authors are Savizkiy V.A. and Terjukova E.U.]). It should be emphasized that such opinion does not only contradicts the separation of powers, but ignores the famous legal principle: «bodies and officials are prohibited everything what the law does not allow straight". Perhaps, V.A. Savizkiy and E.U. Terjukova don't admit to this principle, so they maintain that "basic limits of the laws" concretization by subordinate acts of one or another body are not set down" and if the straight prohibition is absent, everybody, issuing the bylaw, which "considers such concretization as the necessity" can "concretize" the law. Apparently, Savizkiy V.A. and Terjukova E.U. suppose that state-authoritative players are under the principle "it's allowed if it is not prohibited".

${ }^{114}$ Livshitz R.Z. Теория права. M. 109, 1994.

115 Zor`kin V.D. Социалистическое правовое государство: основные черты концепции // Право и власть / Ed. Vishinskyi M.P. M. 83 (1990).
} 
supreme courts can give the law-making decisions, not substituting for the legislator and remaining within the judicial tasks. ${ }^{116}$ Consequently, not the forensic law-making, as such, contradicts the tenet of the separation of powers, but just the law-making activity of the supreme courts ("quasinormative" acts of the judicial power) by the use of abstract normative interpretation of the Constitution or the statute, is at variance with the doctrine. The nature of the judicial power supposes namely specific normative interpretation of the Constitution or the law concerning the pending suite (adhuc sub judice lis est ${ }^{117}$ ). So, everything points to the opinion that just specific (incidental) normative interpretation of the Constitution or the law, resulted in the interpretative precedent, is acceptable. Let even the "quasi-normative" act (example gratia, regulations of the Supreme court) is issued, but this act must not precede judicial practice, but generalize legal stands, that have already put into specific normative interpretation. So, expressum facit cessāre tacĭtum. $\mathbf{1 1 8}^{118}$

Et sic, let's conclude that a political regime isn't a requirement of justice and an instrument for realizing it. Conventional existence of Civil Justice does not depend upon political regime.

This paper intends to represent that there is the deficit of justice in Democratic and hybrid (with democratic features) countries. Also, the gradual legal and political evolution of the European Union has not, thus far, been accompanied by the articulation or embrace of any substantive ideal of justice going beyond the founders' intent or the economic objectives of the market integration project. This absence arguably compromises the foundations of the EU legal and political system since the relationship between law and justice remains largely unaddressed. ${ }^{119}$ "Democracy is not intrinsically just " - professor Richard J. Arneson writes. ${ }^{120}$ Scientists say: "to achieve justice, we need new legislation, new policies, new training, new organizational cultures ". ${ }^{121}$ The Russian experts proclaim the same thing. They agreed that only through the formation of a new corps of judges, reducing the burden on the court, it is possible to achieve effective, high-quality and independent justice. Retired Deputy Chairman of the Constitutional Court of the Russian Federation, member of the Presidential Council for Civil Society and Human Rights Tamara Morshchakova noted that in the context of the ongoing judicial reform there is a danger of "amebiolization" of this process, when the search for solutions to problems in the field of justice occurs not on expert platforms, but on squares ... "We can make claims against journalists and sociologists who turn to citizens for their opinion on judicial reform, but the recipes that are offered cannot be taken seriously, because we are delving into disputes of an unprofessional nature," she explained. $^{122}$

In light of the above reflections, it is indispensable to go beyond the dimensions of the political regime, of the separation of powers, of institutional approach (of "democratic" provisions of Civil Justice) to answer the question: what does conventional existence of Civil Justice depend on? "Justice is an art.." - said Prof. Louis B. Schwartz in the open J. Roberts Memorial Lecture, given at the University of Pennsylvania on October 9, 1986. And we agree.

Let's close the institutional approach to Civil Justice with the Wanderer above the Sea of Fog of Caspar David Friedrich, the epigraph to this article.

The image has been used on the cover of numerous books, as a signifier of mystery, inter alia. We use it as a signifier of justice. Judge is the wanderer on the roads of justice. It is the message conveyed by the painting is one of Kantian self-reflection, meditation, expressed through the

\footnotetext{
${ }^{116}$ Zor`kin V.D. Opt.cit., p.83.

${ }^{117}$ It is still before the court

${ }^{118}$ What is expressed makes what is implied silent

${ }^{119}$ The critical assessment of justice in the EU see here: Kochenov Dimitry, de Búrca Gráinne, Williams Andrew, Europe's Justice Deficit? (2015)

${ }^{120}$ Dowding Keith, Goodin Robert E., Carole Pateman Canberra (eds), Justice\&Democracy, Cambridge University Press, 40-58, (2004)

${ }^{121}$ https://www.minnpost.com/community-voices/2020/06/to-achieve-justice-we-need-new-legislation-new-policiesnew-training-new-organizational-cultures/

${ }^{122} \mathrm{https}: / /$ www.advgazeta.ru/obzory-i-analitika/o-neobkhodimykh-shagakh-k-tsivilizovannomu-pravosudiyu/
} 
judgelwanderer's gazings into the justice that is the sea of fog for everyone, at the start of trial. ${ }^{123}$ Judgelwanderer presents a metaphor for the unknown justice in a pending suit. ${ }^{124}$ The impression the judgelwanderer's position atop the precipice and before the unmindful outlook leaves is sure, suggesting at once mastery over a landscape of law and mind, the insignificance of the individual judging within it. ${ }^{125}$ It is what a judge sees inside himself. Friedrich states his ideas in regards to this, "The artist should paint not only what he has in front of him but also what he sees inside himself." 126

\footnotetext{
${ }^{123}$ Following the analysis of Gorra, Michael Edward in: The Bells in Their Silence: Travels Through Germany. Princeton University Press, 11-12 (2004), https://archive.org/details/bellsintheirsile00gorr/page/11/mode/2up ${ }^{124}$ Following the analysis of Dembo, Ron S; Freeman, Andrew in: The Rules of Risk: A Guide for Investors, Wiley, 10 (January 19, 2001)

${ }^{125}$ Following the analysis of Gaddis, John Lewis in: The Landscape of History. The Landscape of History: How Historians Map the Past. Oxford University Press. 1-2. (2004)

${ }^{126}$ Wanderer Above the Sea of Fog, Caspar David Friedrich (Ca. 1817). Scholastic Art, https://www.theartists.org/wanderer-above-the-sea-of-fog/
} 
Let's open the second part of the article with The Starry Night of Vincent van Gogh. Van Gogh's "Starry Night" is very similar not only to the exact mathematical description of turbulent air flows in the Earth's atmosphere, but also to the supersonic vortices of gas and dust in the "stellar nursery". This is the conclusion reached by scientists who published an article in the arXiv.org electronic library.

"We have shown that 'Starry Night' resembles real turbulence, which directly affects the way we see stars at night. At the same time, the nature of the distribution of energy in the vortices in the picture suggests that it very accurately reflects how the flows behave gas in dense "gas and dust" nebulae, where new stars are born," ${ }^{127}$ - the scientists write.

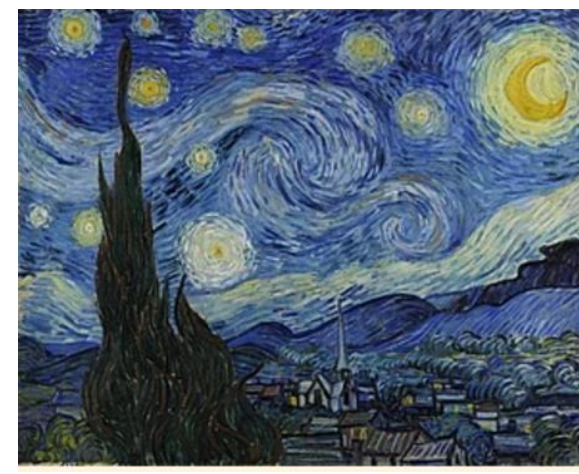

\section{The ideational measurement which affect, navigate and corroborate the Civil Justice.}

\section{Civil Justice, Discretion, Thought, Attention, Awakening.}

We've pointed above that doing justice a judge applies and interprets the legal norms. It is common knowledge that the law is a linguistic proposition that has to be interpreted. Each judge is always obliged to make a judgment, even in cases of vagueness, ambiguity, imprecision, incompleteness of the law. ${ }^{128}$ The judge is continually called upon to "translate" the text of the statute in decisions. Interpretation is a complex and dialectical system. The resolution of a legal dispute is something of procedural, which is based conceptually on three distinct steps: recognition of problem, research of rule to apply, effective application of a norm to issue. ${ }^{129}$

Essentially the legal sciences aspire to establish a true "rational rigour", different from that of mathematics, but no less necessary. ${ }^{130}$ In this context, hermeneutics is configured as the "workshop of living law". ${ }^{131}$ Every interpretative act is always inserted within a specific "living law". The "living law" is a "dialectical synthesis" that incrementally is formed during repeated interpretations of the legal texts. Law, in absolute and general terms, collects the norms of a legal system ("positive law") and the concrete application of these same rules in the judicial context ("living law"). The "living law" is crystallized in the "precedents", in a whole of acts (sentences, ordinances, decrees, etc.) emanated by jurisdictional organs (courts).

Every judge, far from being a "merely mouthpiece of the law", through his interpretation of the formal norms, contributes to the continuing realization of the "living law". ${ }^{132}$

Interpreting and applying the legal norms, the judge thinks and uses the discretion. In our days the discretion is the cornerstone of courts' activity as the decision-making tool is a cornerstone of democracy. Judicial discretion appears as something questionable because the discretion can lead a judge to justice or injustice. ${ }^{133}$

Judicial discretion consists of judge's thoughts. So, what is the judge's thought and how does it connect up with justice?

Applying the quantum mechanics, Peter Baksa ${ }^{134}$ confirms that our brain is comprised of a tight network of nerve cells, all interacting with one another and generating an overall electrical field. Our brain waves are simply the superposition of the multitude of electrical states being formed by our nervous system. Not only our brain, but our entire body has an electric field. Anywhere there's a

\footnotetext{
${ }^{127}$ https://arxiv.org/abs/1902.03381

${ }^{128}$ Marinelli V. Studi sul diritto vivente, Jovene, Napoli, (2008).

${ }^{129}$ Pascuzzi G. Giuristi si diventa, Il Mulino, Bologna, 85 (2008).

${ }^{130}$ Marinelli V, Opt.cit.8.

131 Ibid.

${ }^{132}$ See in: Bobbio, N, Il positivismo giuridico, Giappichelli, Torino (1979); Cappelletti M. Giudici legislatori?, Giuffrè, Milano, (1984).

${ }^{133}$ Papkova O. Opt.cit, 152.

${ }^{134} \mathrm{https} / / /$ peterbaksa.com/huffington-post-peter-baksa
} 
nerve cell, there's electricity. It's just concentrated the greatest around our head because that's where the bulk of our nerve cells are. So, nothing mysterious about that part.

Being an electric field, all those overlying electric wave patterns that comprise our brain waves are governed by the same equations governing the electromagnetic spectrum, light, particles and everything else in the universe. The light seen coming from a star and the energy of our mind are one and the same type.

Our thoughts are formed in this electric field. Judge's thoughts are formed in this electric field. The measurable perturbations and disturbances in the brain's overall electric field are our actual thoughts racing through our mind. The thoughts a judge is thinking of, the words his mind is processing, are all electrical impulses. So thoughts are energy, the same as everything else.

That means they are governed by the rules of quantum mechanics and Schrödinger's ${ }^{135}$ wave equations as well. All those same weird things about quantum mechanics that describe how an electron or photon behave, apply to a judgellawmaker ${ }^{136}$, to anyone and to their thoughts as well. The particle-wave duality, ${ }^{137}$ the uncertainty principle, ${ }^{138}$ and of course, entanglement. ${ }^{139}$ This implies that, like any other set of particles or source of energy,a judge is entangled with everything he has ever encountered in hearings, in judiciary and the rest of the universe through the zero point field. We can think, we are conscious. As such, a judge can choose which of the possibilities before him to collapse his wave function into. But more than that, a judge can thus affect that as well and influence the randomness, just as it can influence him.

Since a judge is conscious, he can choose what part of the randomness around him to be affected by, and how he in turn would like to affect it. It is through the property of entanglement that a judge can affect change. Our minds are transceivers, able to receive and send signals into the "quantum soup" of the zero point field by way of the highly coherent frequencies of our thoughts.

The higher the frequency of judge's thought/brain wave, the higher his consciousness. The level of his consciousness is what makes judge's reality what it is and what it will continue to be..

The level of his consciousness (the frequency of judge's thought $\backslash$ brain wave) is what makes the conventional existence of civil justice reality.

Peter Baksa ${ }^{140}$ writes: if you are seeking change, set an intention, declare a path (align your behaviors with your desire), then detach and allow the universe to handle the details. What is why the judge's thought is very important for achieving justice.

\footnotetext{
${ }^{135}$ One of the greatest physicists of 20th Century, Erwin Schrödinger is known for having a large breath of interests in non-physical disciplines, including biology and philosophy. In particular, his long essay from 1944, What is Life?, has been often mentioned in this respect. Schrödinger's ideas about the structure of material carrier of life, in particular of genetic information, and his ideas about living organisms feeding upon their negative entropy has greatly influenced quite a few prominent biologists of the time. Somewhat less known are his thoughts about the nature of consciousness and the Self included in the same essay as well as in his other works and lectures.

${ }^{136}$ Legislator is a synonym of lawmaker. Lawmaker is a synonym of legislator. As nouns the difference between lawmaker and legislator is that lawmaker is one who makes or enacts laws while legislator is someone who creates or enacts laws, especially a member of a legislative body. Judge could be a lawmaker, doing conscious decision-making. See in detail: Bingham Tom, The Business of Judging. Selected Essays and Speeches (2000).

${ }^{137}$ Wave-particle duality is the concept in quantum mechanics that every particle or quantum entity may be described as either a particle or a wave. It expresses the inability of the classical concepts "particle" or "wave" to fully describe the behaviour of quantum-scale objects. As Albert Einstein wrote: "It seems as though we must use sometimes the one theory and sometimes the other, while at times we may use either. We are faced with a new kind of difficulty. We have two contradictory pictures of reality; separately neither of them fully explains the phenomena of light, but together they do." (Einstein Albert, Infeld Leopold. The Evolution of Physics: The Growth of Ideas from Early Concepts to Relativity and Quanta, Cambridge University Press (1938) https://ui.adsabs.harvard.edu/abs/1938epgi.book.....E/abstract

${ }^{138}$ Heisenberg's uncertainty principle is a key principle in quantum mechanics. Very roughly, it states that if we know everything about where a particle is located (the uncertainty of position is small), we know nothing about its momentum (the uncertainty of momentum is large), and vice versa. Versions of the uncertainty principle also exist for other quantities as well, such as energy and time. https://www.britannica.com/science/uncertainty-principle

${ }^{139}$ Quantum entanglement is a quantum mechanical phenomenon in which the quantum states of two or more objects have to be described with reference to each other, even though the individual objects may be spatially separated.

${ }^{140}$ Peter Baksa has written The Point of Power, It's None of My Business What You Think of Me!,Thinking Yourself Young, which will include interviews with Tibetan Monks from earlier this spring, and The Faith Wave; I think
} 
Ante omnia, a judge has to pay attention to his thoughts as a part of judicial discretion centered on the theory of the separation of powers.

Just the things we pay attention to are alive and the things that do not receive our attention die. It is applicable to everything, to every situation, to every person. It is applicable to Civil Justice, to trial, to a judgellawmaker. It can be explained by quantum mechanics.

The crux of the Law of Attraction ${ }^{141}$ is that whatever a person focuses on will be brought into that person's existence, because the thought becomes directed energy which attracts those things upon which the mind is focused. If a judge $\backslash$ lawmaker focuses on the injustice, more injustice will come. If a judgellawmaker focuses on the justice, more just decisions (the rules of law) will come. In short, "You bring about what you think about". ${ }^{142}$

We should pay attention to judicial discretion, the cornerstone of court's activity to make it "alive" to get the civil justice achievable. "If thoughts can do that to water, imagine what our thoughts can do to us." - from the movie 2004, What the Bleep Do We Know?

Attention is an important moment in every trial because it creates a language inside a judge, which allows him to listen to what surrounds him, to sendlattract the energy. Language which we have already defined as discretion. Discretion is a language of energy. One becomes capable of listening, one becomes receptive. This is the way to nourish the interiority of anyone. And if a trial seems unjust, it is a judge who does not know how to achieve justice, and the secret that it contains. Willigis Jäger says: "Attention is the starting point and heart of all spiritual paths. A careful life is founded on the recognition that reality can only be experienced in the here and now". ${ }^{143}$ The philosopher Edmund Husserl ${ }^{144}$ speaks of the "light" of attention, emphasizing the spiritual value of this ability. ${ }^{145}$ Simone Weil ${ }^{146}$ attaches great importance to attention as the way to ecstasy. She writes: "the highest ecstasy is the attention at its fullest." 147 In the chapter on attention in the Principles of Psychology, William James ${ }^{148}$ writes what on a first reflection might sound rather plausible: "Millions of items of the outward order are present to my senses which never properly enter into my experience. Why? Because they have no interest for me. My experience is what I agree to attend to." ${ }^{149}$ That is, according to James here, justice judge experiences is justice receives his attention or interests him and therefore becomes, is, or remains the object of his experience. In James's words: "Only those items which I notice shape my mind - without selective interest, experience is an utter chaos. Interest alone gives accent and emphasis, light and shade, background and foreground - intelligible perspective, in a word." ${ }^{150}$ If, as James would have it, to experience

\footnotetext{
therefore it is, release date Jan 2012.

${ }^{141}$ We mean the Law of Attraction and Quantum Physics. The Law of Attraction teaches that we attract into our lives whatever we focus on.

${ }^{142}$ It was after the 1970s that these ideas became more popular. Physicist Fritjof Capra wrote the book The Tao of Physics, which compared quantum mechanics with the principles of Eastern mysticism, thoughts also expressed in the 1979 book The Dancing Wu Li Masters by Gary Zukav. In 1985, physicist Nick Herbert wrote Quantum Reality: Beyond the New Physics, which discussed various interpretations of quantum theory, and in 1995, Elemental Mind: Human Consciousness and the New Physics, drawing on the notion that consciousness is a fundamental process of nature. In 1988, Deepak Chopra's book Quantum Healing described the power of the mind to heal the body on a cellular level by tapping into the "intelligence" that lies in every cell. And in 2004, the movie What the Bleep Do We Know offered up a blend of quantum physics, spirituality, neurology, and molecular biology in documentary form to explore the relationship between quantum physics and consciousness.

143 Jäger Willigis, Timeless Wisdom The secret behind all paths to spirituality, (2010)

${ }^{144}$ Husserl's thought profoundly influenced 20th-century philosophy, and he remains a notable figure in contemporary philosophy and beyond.

${ }^{145}$ See in: https://cfs.ku.dk/summer-school-2017/background-readings/Text_Jacobs_2010__revision_2016_.pdf

${ }^{146}$ Simone Adolphine Weil (3 February 1909 - 24 August 1943) was a French philosopher, mystic, and political activist.

${ }^{147}$ The Notebooks of Simone Weil (1951).

${ }^{148}$ William James (January 11, 1842 - August 26, 1910) was the "Father of American psychology"

${ }^{149}$ William James, The Principles of Psychology, Volume I, New York : Dover Publications Inc., $402-403$ (1890).

${ }^{150}$ Ibid
} 
always involves attention or interest that makes discernment possible, then it seems that to experience amounts to being awake. For exercising just discretion, a judge has to be awake. Here Awakening is not a metaphor: basic wakefulness is the effects of Buddhist meditation practices. Mindfulness meditation has a long-standing history in Eastern practices that has received considerable public interest in recent decades. These practices have become a topic of widespread interest in both science and medicine, also. Mindfulness-based stress reduction can often help people address stress, chronic pain, cancer, anxiety, depression, and other chronic issues. Mindfulness-based injustice reduction can often help judges Vawmakers address injustice. In this article, we discuss the concept of mindfulness and describe its implementation in acheiving justice as the treatment of injustice. In an attempt to counterbalance the plethora of data dealing with effects and implementation of interventions of Buddhist meditation, we aim to provide evidence of meditation's arousing or wake-promoting effects by drawing both from Buddhist textual sources, from legal and scientific studies.

Awakening is a complex problem. We base on well-established ideas from the complexity theory, mentioned above. ${ }^{151}$ The study published in Physical Review Research ${ }^{152}$ is potentially applicable to humans (to a judgellawmaker). The research team studied the brain signals produced by 13 fruit flies both when they were awake and when they were anesthetized. They then analyzed the signals to see how complex they were. "We found the statistical complexity to be larger when a fly is awake than when the same fly is anesthetized," the team said. This is a major problem in justice, where it is crucial to differentiate between sleeping judges and those who are awake. "The study is significant because it highlights an objective way to measure conscious arousal, based on wellestablished ideas from complexity theory," the team said. "It is potentially applicable to humans and it reflects a growing interest in new theories of consciousness ${ }^{153}$ that are experimentally testable."

This is especially important in the study of judiciary, judicial and law changes, and lawmakersljudges, where complexity theory can offer insights into how courts become more just (fair), accessible, sustainable, adaptive, and innovative.

A basic feature of the mindfulness approach is the close link with scientific thought and research: it was born among people who are scientists, researchers, clinicians and immediately developed in practical experimentation. It started from rigorous scientific researches that try to verify its effective efficacy and functioning mechanisms. Today, research on various issues related to the perspective of mindfulness is a very "hot" area of science. It's in exponential expansion, with several hundred research articles published every year in the leading scientific journals of different fields.

\section{Civil Justice and Discretion as its language.}

Judicial Discretion is under the doctrine of the separation of powers, it is one of the aspects of judicial independence. ${ }^{154}$

\footnotetext{
${ }^{151}$ Complexity Theory allows us to better understand systems as diverse as cells, human beings, forest ecosystems, and organizations, that are only partially understood by traditional scientific methods (Zimmerman, B. Complexity Science: A Route through Hard Times and Uncertainty. Health Forum Journal 42-46 (March/April 1999); Zimmerman, B. Lindberg C. and Plsek P. Edgeware: Insights from Complexity Science or Health Care Leaders. Irving Texas: VHA, Inc, (1998. ). While it represents a relatively nascent field of study, it spans across a wide variety of disciplines in the physical, biological, and social sciences, and has profound implications for the way we think about and act within the world (Schneider, M\&Somers,M. Organizations as complex adaptive systems: Implications of Complexity Theory for leadership research. The Leadership Quarterly, 17(4), 351-365(2006): https://doi.org/10.1016/j.leaqua.2006.04.006 ).

${ }^{152}$ General anesthesia reduces complexity and temporal asymmetry of the informational structures derived from neural recordings in Drosophila by Roberto N. Muñoz, Angus Leung, Aidan Zecevik, Felix A. Pollock, Dror Cohen, Bruno van Swinderen, Naotsugu Tsuchiya and Kavan Modiay, 22 May 2020, Physical Review Research.

${ }^{153}$ Conscoiusness is to be awake, inter alia. https://franciewhite.com/consciousness-cosmology-physics-definitionsterms-for-beginners/

${ }^{154}$ Cartabia Marta, Separation of Powers and Judicial Independence: Current Challenges, European Court of Human Rights, the Authority of the Judiciary, Seminar in the occasion of the Solemn Hearing of the Court Strasbourg (January 26th, 2018). See also: https://en.wikipedia.org/wiki/Judicial_discretion
} 
We look at the discretion hidden behind achieving civil justice, the meanings that are not seen, as at the invisible language. Paolo Dall'Oglio ${ }^{155}$ says: "In dialogue, if we want to avoid dialogue between the deaf, it is necessary to build a common language made up of arguments drawn from both a profound and wise textual and literary tradition; in fact, each must learn the spiritual language of the other.." ${ }^{156}$ Discovering that the discretion is a language brings us back to the essence of law, to that thrill that is revealed only to those who have understood the secret of law. And after having grasped it and deposited it in the high regions of the human being, after having admired it and lost in contemplation, reformulate the discretion with words, sentences, orders, judgements and give them back to others so that they may have a renewed experience. These are the ways of civil justice that allow the manifestation of hidden discretion. Lawmakersljudges need to visit this sublime plan that supports them to give new meaning to discretion and penetrate the justice of reality.

The just (fair) discretion depends on the fundamental questions that the lawmakerljudge asks, on his principal thoughts, their direction. It is this that illuminates the meaning of discretion. One of these questions (thoughts) is about justice and him in it. If a lawmakerljudge considers justice in every trial a totality, which is reflected in its parts and therefore also in a Justice which is its highest part, a profound sense of belonging to the mystery in which a judge is and which generates reverence, that cosmic justice, arises which produces love, beauty, sharing, solidarity and participation, which also becomes care for each of its elements. This is the reflection that a lawmakerljudge, who makes acquaintance with Justice, leaves to others. And so with every decision he packs a "package" in which he tells what conventional existence of civil justice is and what justice is. And looking for the meaning of the many decisions a lawmakerljudge has done and the many his discretions regarding cases and parties, he draws a fresco of the great passions of his space-time. If we ask a lawmakerljudge at the end what he leaves, he leaves a justice that maybe will help someone to see the world in a just way, to enjoy their life more, to see it in a bigger context, like what he feels so strong.

At the end of life famous A.F. Koni ${ }^{157}$ said: "I have lived my life in such a way that I have nothing to blush. I loved my people, my country, I served them, how I could. I'm not afraid of death. I fought a lot for my people, for what I believed in."

The challenge of discretion as the justice's language to describe it and its effects on achieving justice remains because that challenge stems from the fact that discretion is essentially an experimental process and not an academic concept.

\section{Civil Justice, Discretion, Mindfulness.}

Judge thinks, using discretion and achieving justice. Mindful thinking is the ability to be aware and conscious of your thoughts. Mindful judicial discretion is to be aware and conscios of your thoughts regarding application and interpretation of legal norms in a just way. To ground yourself in the present trial, acknowledging what you are thinking and feeling - but without being reactive to it. Being mindful judge means being aware of your thoughts, emotions, and how you're feeling both physically and mentally.

\footnotetext{
${ }^{155}$ Father Paolo Dall'Oglio (born November 17, 1954) is an Italian Jesuit priest and peace activist. He was exiled from Syria by the government in 2012 for meeting with members of the opposition and criticizing the actions of the Syrian government during the Syrian civil war. He was kidnapped by Islamic State of Iraq and the Levant on 29 July 2013. See: https://alisariram. wordpress.com/the-story-of-father-paolo-dalloglio-and-the-picturesque-craggy-deir-mar-mousaof-the-lovely-frescoes-where-he-lived-and-preached-love/

${ }^{156}$ Dall'Oglio, Paolo, Innamorato dell'Islam, credente in Gesù (aprile 2011)

${ }^{157}$ Anatoly Fedorovich Koni, 1844-1927, was a Russian jurist, judge, politician and writer. He was the most politically influential jurist of the late Russian Empire. He led the investigations of a number of high-profile criminal cases, including The Borki train disaster occurred on October 29, 1888 (Miller Frederic P, Vandome Agnes F, McBrewster John (eds) Borki train disaster: Kharkov Governorate, Kharkiv Oblast, Royal train, Tsar, Crimea, Saint Petersburg, Alexander III of Russia (2010) about the shipwreck Vladimir, was the author of such works as "Fathers and Sons of Judicial Reform", "Judicial Speeches" and "On the Path of Life". Among his contemporaries, Koni became famous as an outstanding orator.
} 
Over the past few decades, mindfulness meditation has become increasingly popular. A woolly concept for many, mindfulness has been described as being "not about feeling better, it is about being better at feeling". The Oxford on-line dictionary describes mindfulness as, "A mental state achieved by focusing one's awareness on the present moment, while calmly acknowledging and accepting one's feelings, thoughts, and bodily sensations, used as a therapeutic technique". While many empirical studies have confirmed that regular mindfulness meditation can have beneficial effects on people's well-being, so far very little is known about the contribution of mindfulness to judicial discretion and civil justice.

The impact of mindfulness is already widely recognised and appreciated in the fields of medicine, psychology, education and business but the legal profession has been slower to accept and integrate its transformative effects. Meditation retreats for lawyers are still relatively rare on this side of the world however in the US they are more common. The fact that lawyers are more sceptical than most, is perhaps the key reason why mindfulness has been slower to take off in the legal profession. The reported benefits of mindfulness meditation practice are numerous and varied. These include reduced stress, improved well-being, increased immune functioning, boost to memory and focus, increased relationship satisfaction enhanced self-insight, morality and intuition. Some benefits of mindfulness are obvious but others, no less important, are less so because they are more subtle. Legal academics cite these additional potential benefits, as follows:

1.Increasing the ability to transcend the dominating influence of the traditional adversarial mind-set to allow awareness of other perspectives;

2.Developing the skill of deep and open listening;

3.Developing negotiation skills by training in the maintenance of a delicate balance (in understanding, emotion and behaviour) necessary for making wise decisions;

4.Fostering the ability for calm deliberation, which promotes better decision-making in difficult situations;

5.Cultivating trial advocacy skills by developing internal abilities to, for example, remain centred in challenging moments in court and retain authenticity;

6.Enhancing the performance of traditional legal tasks, such as learning, understanding and manipulating rules of law, drafting documents and litigating cases;

7.Enhancing ethical practice through, for example, developing the self-reflection skills important to judgment and also because mindfulness makes it more likely that one will adopt universal norms such as honesty and fairness;

8.Making the practice of law more meaningful and satisfying generally;

9.Expanding focus to include broader orientations towards lawyering (for ex ample, restorative justice, therapeutic jurisprudence, collaborative law and other healing, peace-making perspectives). ${ }^{158}$

Charles Halpern ${ }^{159}$ says: "Lawyers survive in a sea of interconnected relationships. Emotional intelligence (EQ) is absolutely necessary. Mindfulness builds the muscle of EQ" ${ }^{160}$ Halpern is adamant that the present time is fertile ground for the practice of mindfulness and that it is teachable and learnable. Lawyers operate and work within the context of complex human situations predominantly situations of conflict and stress - and attempt to apply a body of external laws, rules and practices to resolve those situations and conflicts. This is within a framework of time, financial,

\footnotetext{
${ }^{158} \mathrm{https}: / /$ www.theconsciouslawyer.co.uk/mindful-lawyering/

${ }^{159}$ Charles Halpern is a lawyer, activist, author, educator, and meditation practitioner. He also served as the founding dean of CUNY School of Law, and as a faculty member of various prominent law schools across the country. Halpern is considered a pioneer in public interest law, responsible for various entrepreneurial and educational initiatives that contributed to legal, academic, social justice, and contemplative communities. He is founder of the Initiative for Mindfulness in Law (an innovative programme exploring the benefits of mindfulness to legal education and law practice at Berkley University, California) and one of the key thought-leaders for the mindfulness and law movement in the US, Halpern's book, Making Waves and Riding the Currents: Activism and the Practice of Wisdom, tells the story of how he brought public interest activism, mindfulness, and meditation into law schools and courthouses across the United States. https://greatergood.berkeley.edu/profile/charles_halpern

${ }^{160} \mathrm{https}: / / \mathrm{www}$.theconsciouslawyer.co.uk/mindful-lawyering/
} 
epidemic and other external pressures. Little is done to educate and train lawyers - whose discretion tends to focus on the external, and to rely on 'thinking', 'judging' and 'action' - on the equal value and benefits of focusing on the internal, and relying on 'not thinking', 'not judging' and 'not acting'. This is exacerbated by the fact that analytical personality types ${ }^{161}$, with a tendency to process information intellectually and look for guidance from external sources, are attracted to the field of law.

We hypothesize that:

- Civil justice depends upon the judicial discretion,

- the judicial discretion is based on legal consciousness,

- legal consciousness is the necessary part of the road to justice,

- legal consciousness makes the part of consciousness, there are the awareness and mindfulness, too, the consciousness, the awareness and the mindfulness are the conditional parts of the road to justice.

The mindfulness means awareness (consciousness) but in a particular sense. It refers first of all to direct experience. As we have understood earlier the experience deals with paying attention. Among the possible descriptions, that of Jon Kabat-Zinn, one of the pioneers of this approach, has become "classic": "Mindfulness means paying attention, but in a particular way: a) with intention, b) in the present moment, c) in a non-judgmental way". ${ }^{162}$ It can also be described as a way to cultivate a fuller presence in the experience of the moment, in the here and now.

It sic, regarding civil justice the mindfulness means attention with intention in a present trial in a non judgmental way. It can also be described as a way to achieve a fuller justice's presence in the trial.

Attention. In the field of civil justice, attention (experienced-based practice) is essential in validating the judicial discretion within the societal lscientificllegal community. Discretio est discernere per legem quid sit justum. ${ }^{163}$ Accordingly, there is an ongoing need to diligently reassess the discretion a judge exercises in a trial to ensure the conventional existence of Civil Justice. Mindfulness is a general term for using the "present moment as the core indicator of the appropriateness of particular choices" (Kabat-Zinn, 1994).

Intention. At its base, mindfulness is a natural human state in which an individual experiences and attends to the present moment. Recently an intervention based on the Buddhist principles of awareness, called mindfulness, has become increasingly prevalent as an adjunct intervention in clinical settings. In our settings, mindfullness in justice is a natural human state of a judge in which he uses discretion ${ }^{164}$ and attends to the present trial.

Mindfulness can be incorporated into other reforming modalities as part of an integrated approach to achieving justice: law reform or judicial reform. An effective legal and judicial reform strategy in most countries requires a comprehensive approach that includes: repeal (removal or reversal of a law), creation of new law, consolidation (combination of a number of laws into one), codification

\footnotetext{
${ }^{161}$ The analytical personality type is very deep and thoughtful. They're serious and purposeful individuals. They set very high standards, so they have very high standards of performance personally and professionally. Analyticals are orderly and organized. They also tend to have that really dry but witty sense of humor. Analytical strengths are that they are perfectionists. They want things done right and they want them done right the first time. They're neat and tidy individuals. Analyticals are economical, and they are self-disciplined. Analyticals weaknesses are that they can be moody, critical, and negative. Analyticals can be indecisive and they over-analyze everything. Their perfectionism can also manifest as a weakness at times, as they can be guilty of making their pursuit of perfection stall completion. See: https://crestcom.com/blog/2015/11/24/4-personality-types-that-all-leaders-should-learn-to-recognize/\#: :text=1.,Analytical,Analyticals\%20are\%20orderly\%20and\%20organized.

${ }^{162}$ Kabat-Zinn, J. Wherever you go, there you are: Mindfulness meditation in everyday life. New York: Hyperion, 4 (1994)

${ }^{163}$ Discretion is the selection of that which is just by the law.

Discretion is to discern through law what is just. Discretion in legal practice means the equitable decision of what is just and proper under the circumstances. It is the power of a judge, in certain matters, to decide in accordance with his own judgment of the equities for the cases, unhampered by inflexible rules of law. The latitude allowed to judges as to the action to be taken on certain facts.

${ }^{164}$ Discretio est discernere per legem quid sit justum.
} 
(collection and systematic arrangement, usually by subject, of the laws of a state or country), a program on training and education, improvements to appointment and promotion processes, better disciplining mechanisms, transparency in procedures and decision-making. ${ }^{165}$

Unjust judicial discretion leads to injustice. Even judge's unjust thoughts can accumulate and/or spiral out of control, leading to injustice. ${ }^{166} \mathrm{We}$ advance to realize, however, that mindfulness can be of great benefit, as it can enable the judge to become better able to separate himself from unjust thoughts, emotions, and bodily sensations that may be present, often before they become too overwhelming, entering into judicial discretion.

Mindfulness-based interventions ${ }^{167}$ can be used to address a range of justice's concerns. Interventions have to train judges how to put this practice into every trial. Those judgesllawmakers who are able to achieve this state of awareness may find it easier to then implement other reformal strategies. This article provides a basis for incorporating these interventions into achieving justice.

Non judgmental way. A judge is a person. But a judge can't judge as an ordinary person. The mind of every person is a judging machine. Everything that we experience is filtered, categorized, and dealt with in some automatic way. Some things are judged as "good", so we grasp for more, and cling to what we have. Other things are judged as "bad", so we hide, resist, and run away from them. And everything else? That's judged as "neutral", so for the most part, we ignore it entirely. Judgment toward ourself, others, or events has impacted our life in ways that feel limiting, inauthentic, or harmful in some way. Setting down the judging mind is a refreshing weight off of judge's shoulders. A judge should let go of the automatic judgments that arise in his mind with every experience he has. He has to do justice, to use discretion as a judge, to apply and interpret legal norms as a judge, to judge as a judge ${ }^{168}$. To be a judge is a vocation of a special person. Halpern says: "Legal education and the legal profession, like society at large, are in a period of transition. Lawyers and law students today face unprecedented challenges, from upheaval in the legal market, to seismic shifts in health care, financial markets, the environment and other sectors. In order to thrive and effectively service their clients in this time of uncertainty, legal professionals need new skills, and I believe deeply that one of them is mindfulness, the ancient practice of moment-by-moment, non- judgmental awareness." ${ }^{169}$ These words written in the context of the American legal system apply equally in a global context, because the difficulties and issues described by Halpern are faced by lawyers in jurisdictions across the world, including Italy and Russia. Halpern and others like him advocating the potentially transformative effect of mindfulness in law are laying the foundation and paving the way for an urgently needed movement within the law that can, hopefully, only gain momentum. Such foundation and such way are applicable for every judgellawmaker, independently from the political settings.

We hypothesize that the Civil Justice in "un \democratic", any, settings depends significantly upon the synthesis of the "democratic" foundations, principles, established by law, and some top value that a judgellawmaker is devoted to serve. Also Ivan Ilyin wrote about the idea of serving the

\footnotetext{
${ }^{165} \mathrm{https}$ ///sdgaccountability.org/working-with-formal-processes/pursuing-law-reforms-strategic-litigation-and-legalempowerment/\#easy-footnote-bottom-1-611

${ }^{166}$ Here we base on the mind-body problem. It is a debate concerning the relationship between thought and consciousness in the human mind, and the brain as part of the physical body. It is distinct from the question of how mind and body function chemically and physiologically, as that question presupposes an interactionist account of mind body relations. See: Skirry, Justin, Rene Descartes: The Mind-Body Distinction, Internet Encyclopedia of Philosophy (2016). "The real distinction of mind and body based on their completely diverse natures is the root of the famous mind body problem: how can these two substances with completely different natures causally interact so as to give rise to a human being capable of having voluntary bodily motions and sensations?"This question arises when mind and body are considered as distinct, based on the premise that the mind and the body are fundamentally different in nature.

${ }^{167}$ In clinical settings the mindfulness-based interventions are generally aimed at relieving symptoms of stress, mental health concerns, and physical pain.

${ }^{168}$ About the History, Meaning, and Use of the Words Justice and Judge (Jason Boatright) see in St. Mary's University School of Law: https://commons.stmarytx.edu/thestmaryslawjournal/vol49/iss4/1/

${ }^{169} \mathrm{https}: / / \mathrm{www}$. theconsciouslawyer.co.uk/mindful-lawyering/
} 
highest value. ${ }^{170} \mathrm{We}$ have found the same idea in the thoughts of Pierre Teilhard de Chardin SJ ${ }^{171}$, Teodosij Dobžanskij ${ }^{172}$, Anne Dambricourt-Malassé ${ }^{173}$ and others. We put forward the idea about the evolution towards Wellbeing, Justice through Mindfulness. We don't use the term Evolution in its Darwinian-Lamarckian sense. We use it in J.J. Hurtak's ${ }^{174}$ sense: true evolution is spiritual evolution. In particular, we use insights from the scientific knowledge to examine how evolution of mind have informed and been informed by wider changes in science (labs) to achieve justice and wellbeing.

Max Planck says: "All matter originates and exists only by virtue of a force which brings the particle of an atom to vibration and holds this most minute solar system of the atom together. We must assume behind this force the existence of a conscious and intelligent mind. This mind is the matrix of all matter." ${ }^{175}$

Michio $\mathrm{Kaku}^{176}$ recently caused a small shock in the scientific community by claiming to have found evidence of the existence of an unknown and intelligent force that governs nature. "I came to the conclusion that we are in a world made up of rules created by an intelligence, not very different from a computer game, but of course, more complex," said the scientist. ${ }^{177}$

What we perceive with our five senses is not reality. Quantum physics has shown that space and time are illusions of perception. An experiment at the University of Manchester revealed that the shape of the interior of an atom is almost entirely empty space. The question then became how a judgellawmaker could possibly make the Civil Justice see him. Our true consciousness does not exist in our brains or in our bodies, but this illusion of our individual bodies has manifested the idea that we all think independently from one another, that judges llawmakers all think independently from one another. With this understanding it seems possible to scientifically explain telepathy, clairvoyance, spiritual mediums related to the transfer of information between sources without physical means of communication phenomena. When we understand that there is a common spiritual bond between all things in the universe and that we are all part of a divine intelligence, that judges are all part of a cosmic Justice, this simple understanding will fill all the holes in modern civil justice included judicial discretion. A judge is just (fair) and his justice is immortal and timeless, once he identifies with the eternal realitym the cosmic Justice, and consistent with the quantum vision, he will enter the new paradigms of quantum consciousness. ${ }^{178}$

\footnotetext{
${ }^{170} \mathrm{https} / / /$ www.tstu.ru/book/elib/pdf/st/2008/moskaleva.pdf

${ }^{171}$ Pierre Teilhard de Chardin SJ $(1881$ - 1955) was a French idealist philosopher and Jesuit Catholic priest who trained as a paleontologist and geologist and took part in the discovery of the Peking Man. He conceived the vitalist idea of the Omega Point (a maximum level of complexity and consciousness towards which he believed the universe was evolving), and he developed with Vladimir Vernadsky the concept of noosphere. Teilhard's ideas had a profound influence on the New Age movement. The idea of the Omega Point is developed in later writings, such as those of John David Garcia (1971), Paolo Soleri (1981), Frank Tipler (1994), and David Deutsch (1997).

${ }^{172}$ Theodosius Grygorovych Dobzhansky $(1900$ - 1975) was a prominent Soviet-American geneticist and evolutionary biologist, and a central figure in the field of evolutionary biology for his work in shaping the modern synthesis.

${ }^{173}$ Anne Dambricourt-Malassé (born in 1959), researcher in human palaeontology at the CNRS, Paris, France, secretary general of the Teilhard de Chardin Foundation, offers a bold thesis on the evolution of living things.

${ }^{174}$ J.J. Hurtak (born 1940, sometimes referred to as James Jacob) is an American social scientist, linguist, futurist, and author. Hurtak's work encompasses a diverse array of disciplines, including religion and philosophy, space law, environmental sciences, remote sensing, and unconventional theories in the fields of planetary sciences and archaeology. Through the "Academy for Future Science," Hurtak works internationally to encourage people to embrace new and emerging technologies.

${ }^{175}$ Planck Max, in Archimedes to Hawking: Laws of Science and the Great Minds Behind Them, Oxford University Press, 417 (19 March 2008)

${ }^{176}$ Michio Kaku (January 24, 1947) is an American theoretical physicist, a professor of theoretical physics in the City College of New York and CUNY Graduate Center. He is famous for formulating the revolutionary string theory (model of fundamental physics which assumes that apparently specific material particles are actually "vibrational states"). He has written the New York Times best sellers Physics of the Impossible (2008), Physics of the Future (2011), and The Future of the Mind (2014).

${ }^{177}$ https://www.nbcnews.com/mach/science/michio-kaku-sees-amazing-things-our-future-except-those-scaryncna851226

${ }^{178}$ See: Valverde Raul, Quantum Consciousness \& Spirit, Journal of Consciousness Studies 10(3):167-181 (April
} 
We advance a theory that the conventional existence of civil justice corresponds to the present ("living") level of a lawmakerljudge - to the level of his spirituality. As minimum, a judge has to have mindful legal consciousness.

When we say about the spirituality, it is necessary to clarify what is meant. Spirituality is not a religion. There are some pretty clear ways in which religion and spirituality differ. ${ }^{179}$ There are wider concerns about the idea of introducing practices, traditionally seen as having a strong religious association, into a secular setting. Norman Fisher ${ }^{180}$ says: "These teachings are those of humanity, even though they may have originated 2,600 years ago. They can be taught in secular settings." 181 Daniel J Siegel ${ }^{182}$ says: "Oftentimes, people hear the word 'mindfulness' and think 'religion', but the reality is that focusing our attention in this way is a biological process that promotes health - as a form of brain hygiene - not a religion. Various religions may encourage this health-promoting practice, but learning the skill of mindful awareness is simply a way of cultivating what we have defined as the integration of consciousness."

Spirituality depends on practice. ${ }^{183}$

Spirituality develops when we dedicate our freedom to something greater and more important than ourselves, with which we identify. A judge develops spirituality when he dedicates his freedom to justice, with which he identifies. In order to achieve justice, a judge must go out of himself. The spiritual person is a mindful person or with other words: the mindful judge is a spirtual person. The spiritual (mindful) judge works on his own interiority, but uses the body, he is aware that as a body he depends on nature, as a judge he depends on the judiciary, law, the rule of law, he knows that there is a human dimension of justice that cannot be reduced to the bios, nor to the judiciary, it is free, where the judge can act with discretion, he can create justice that was not there before, the judge knows that he can move away from a legal norm; he knows that freedom is precious and therefore must be cared for, supervised, disciplined, and that the justice happens if the judge relates to a larger dimension, to superior intelligence, to top values.

Conventional existence of Civil Justice depends on the legal consciousness; the spirituality and culture; political experience of a state in historical perspective; geographical location of a state; etc. We advance the theory that the Judicial Discretion ranks with the level of legal consciousness. We contribute to debates whether the problems of Civil Justice are resolved on the basis of the

\footnotetext{
2019).

${ }^{179} \mathrm{https}$ ://au.reachout.com/articles/what-isspirituality\#: :text=There\%20are\%20some $\% 20$ pretty\%20clear,sense $\% 20$ of\%20peace\%20and $\% 20$ purpose.

${ }^{180}$ Zoketsu Norman Fischer is an American poet, writer, and Soto Zen priest, teaching and practicing in the lineage of Shunryu Suzuki (Shunryu Suzuki, often called Suzuki Roshi. May, 1904 - 1971) was a Sōtō Zen monk and teacher who is renowned for founding the first Zen Buddhist monastery outside Asia (Tassajara Zen Mountain Center). Suzuki founded San Francisco Zen Center which, along with its affiliate temples, comprises one of the most influential Zen organizations in the United States. A book of his teachings, Zen Mind, Beginner's Mind, is one of the most popular books on Zen and Buddhism in the West). He is a Dharma heir of Sojun Mel Weitsman, from whom he received Dharma transmission in 1988. Fischer served as co-abbot of the San Francisco Zen Center from 1995-2000, after which he founded the Everyday Zen Foundation in 2000, a network of Buddhist practice group and related projects in Canada, the United States and Mexico (http://everydayzen.org/about-everyday-zen/teachers/ ). Fischer has published more than twenty-five books of poetry and non-fiction, as well as numerous poems, essays and articles in Buddhist magazines and poetry journals (https://www.normanfischer.org/biography/).

${ }_{181} \mathrm{https}$ ://www.garrisoninstitute.org/images/Its_all_in_the_mind.pdf

${ }^{182}$ Daniel J. Siegel (born July 17, 1957) is a clinical professor of psychiatry at the UCLA School of Medicine and executive director of the Mindful Awareness Research Centre.

${ }^{183}$ See interview with Santikaro (Robert Larson), who had trained under the famous Thai Buddhist teacher, Buddhadasa Bhikku. According to him, in the west, there are three forms that mindfulness has been shaped into: https://www.huffpost.com/entry/is-there-anything spiritu_b_8021384?guccounter=1\&guce_referrer=aHR0cHM6Ly93d3cuZ29vZ2x1LmNvbS8\&guce_referrer_sig=A QAAACyXEo42DAtwGm2DqjM0ujjORlHn5Qx-

iTmzhDGlHx2JCCqKzs5gBcS0irWpIBxDnpzfrE167YQYyGHJOGg_PgaesyBq-XniWAsmuLMb-S5YvNCbdWKTVx9qjQPfs1ZZMU4D-NqM6vuoVM9IBLWTRfbOJFmXODfu2FJ-HbuZ4Ym
} 
correspondence of legal consciousness with the basic legal principles to counterbalance the liberal idea of universalism. ${ }^{184}$

In line with this interpretation, our analysis advises any specific system as for democratic states so for transition and developing economies and suggests that institutional development and academic research should aim at identifying the contextual circumstances which affect the costs and benefits of the different solutions.

We hypothesize that in Russia the democratic foundations, especially of civil justice, stated by law, but not followed from the historical, cultural, political development of Russia, result in the crisis of the legal consciousness of a judgellawmaker. ${ }^{185}$

We advance the idea that the justice's problems are the failure of judicial discretion and the result of the legal consciousness`s deformation and blemish.

In line with this point we hypothesize that the Judicial Discretion is the art of law as the justice is the art. Law is a living organism. ${ }^{186}$ It is based on a factual and social reality that is constantly changing. ${ }^{187}$ According to our conclusion the establishment of judicial discretion by the rule of law is not the judgellawmaker's whim but the result of development of statelcommunity, law, spirituality. To what a judgellawmaker pays attention dipends upon such development. ${ }^{188}$ Here our starting point is that the Civil Justice concerns the "democratic" foundations, stated by law, e.g judicial independence, the-rule-of-law state, access to fair justice.

The analysis carried out in this paper, although still incomplete, suggests not only that the concept of civil justice needs a better definition, but that its main dimensions, including the phenomenon of judicial discretion with the special attitude to legal consciousness, should be taken into account for their different impact.

\section{Does conventional existence of Civil Justice depend upon legal consciousness?}

We hypothesize that to comprehend the conventional existence of Civil Justice, the new philosophy of the legal consciousness is necessary. We advance the idea that the conventional existence of Civil Justice is defined by the standard of the official legal consciousness. We debate on the meaning of the integration of human interest (of a judgellawmaker) and state interest on the ground of the common aim, rooted in their uniform spiritual culture. We hypothesize that (1) the main substance of politics comes to indissoluble identity of human and state interests; (2) politics is the art to unite of humans.

Nikolai Berdjaev ${ }^{189}$ (1874-1948) does not believe in democracy; better: he does not believe in materialist democracy, which arises from demagogy that is from the fondling of the lowest instincts of crowds.

Man is not a simple individual; he is, or must strive to become, a personality. "Man is a personality not by nature but by spirit. By nature he is only an individual" ${ }^{190}$ : this is the anthropology of the Russian philosopher Nikolai Berdjaev.

\footnotetext{
184،By universalism, I mean the assumption that knowledge, justice and personal development are to be found in the universal rather than the particular; that the progression should be away from particular facts towards universal laws, away from particular judgements towards general principles, away from one's "parochial" origins towards a cosmopolitan sensibility or the universal fellowship of the human spirit. In each area, the universal is given priority." See: Boyle James, Universalism, Justice and Identity Politics: From Political Correctness to Constitutional Law (2000), https://law.duke.edu/boylesite/identity.htm

${ }^{185}$ See about the issue: Silbey Susan S, Studying legal consciousness: Building institutional theory from micro data, Droit et société Volume 100, Issue 3, 733-788 (2018) https://www.cairn-int.info/article-E_DRS1_100_0733--studyinglegal-consciousness-building.htm

${ }^{186}$ Dickson Brian, A Life in the Law: The Process of Judging, 63 Sask. L. Rev.373, 388 (2000), Cardozo Benjamin N., The Paradoxes of Legal Science 10-11 (Greenwood Press 1970) (1928).

${ }^{187}$ Rehnquist William H, The Changing Role of the Supreme Court, 14 Fla.St. U. L. Rev., 1.

${ }^{188}$ Papkova O.А. Судейское усмотрение (Usmotrenie Suda), Moscva, 64-199 (2005)

${ }^{189}$ Nikolai Berdyaev is a Russian thinker who offers the enquiring foreigner a window into Russia's soul.

${ }^{190}$ Berdyaev N. Slavery and Freedom, 21, (1939)
} 
For Berdjaev, the truth is found in the personality, not in the individual: the individual is such for a purely biological and social fact; but his inner truth, his vocation, the purpose of his entire existence, emerge only when he sets out to become a personality, realizing his own ontological potential, which is extra-natural and participates in the divine.

For us the civil justice is found in the personality of a lawmakerljudge, not in being judgellawmaker separate from other judgeslawmakers and possessing their own needs or goals, rights and responsibilities: the individuality of a lawmakerljudge is such for a purely careerleducation and social fact; but justice is his inner truth, his vocation, the purpose of his entire existence, emerge only when he sets out to become a personality, realizing his own ontological potential, which is extra-natural and participates in the Universe, in cosmic Justice.

Let me also turn to M. Norbekov ${ }^{191}$ : to the provocative titles of his books ${ }^{192}$, to the deep interesting content of his method ${ }^{193}$, and to his excellent results ${ }^{194}$. In his Key to Insight, he explains in detail that first you need to learn to smile, rejoice and be content, and then health, wealth, and love will come. But not vice versa!!! The formula "Give first, and then I will be satisfied" does not work. Following this theory first a judgellawmaker needs to learn to be just, to be in justice and then justice will come.

Let's return to "What we perceive with our five senses is not reality" 195 , utilyzing the Holonomic brain theory, also known as The Holographic Brain, a specific theory of quantum consciousness. ${ }^{196}$ It describes human cognition by modeling the brain as a holographic storage network. ${ }^{197}$

Following this theory the separation between judges, between court and key figures of a trial, like the separation between particles, as between everything that makes up the universe, is an illusion. Reality is the greatest illusion than we can imagine. Justice as reality is the illusion. Everything that surrounds us is the result of a frequency, so if the frequency is changed the structure of matter changes in turn.

In 1982, the French physicist Alain Aspect, director of the CNRS, carried out an extremely important experiment: he noticed that by subjecting some subatomic particles (in this case electrons) to certain conditions, they were able to communicate simultaneously regardless of the distance that separated them (millimeters or billions of kilometers); the subatomic particles were somehow connected in a non-local way. This experiment intrigued the British physicist David Bohm, who understood that the separation between particles, as between everything that makes up the universe, is an illusion. At a deeper level of reality and vibrations "everything is connected with everything", particles exist as extensions of the same "fundamental organism". Everything appears separate to us because we are able to perceive only a certain level of reality, so the universe itself is an immense projection, a hologram.

Many scientists now believe the brain and body operate on holographic principles on the cellular, molecular, and neural levels. Holographic theory helps us to understand social sciences systems, inter alia, Civil Justice system by stressing the wholeness of the system. Individual components of a system cannot be manipulated without affecting all other components in the system.

\footnotetext{
${ }^{191}$ Professor Mirzakarim Norbekov has a doctor's degree in psychology, pedagogy and medicine philosophy. He is a member of several international academies, a developer of patented inventions and a best-seller author. He is an ardent martial artist with a black belt and a third Dan in Karate.

${ }^{192}$ Опыт дурака 1, или Ключ к прозрению Opyt duraka 1, ili Klyuch k prozreniyu (Russian) - Fool's experience or Key to Insight (January 1, 2019)

${ }^{193}$ The method by which Prof. Norbekov has helped countless people to heal themselves is based on a thousand-year old Eastern doctrine, Sufism. It builds on the knowledge that man, as a unity of body, mind and soul, has astounding inner potentials, which he can activate at any time.

${ }^{194}$ In the case of diseases, man can bring his soul back into harmony with its true nature, and thus heal himself.

${ }^{195}$ Mentioned above.

${ }^{196}$ It was developed by neuroscientist Karl Pribram initially in collaboration with physicist David Bohm building on the initial theories of Holograms originally formulated by Dennis Gabor.

${ }^{197}$ Forsdyke D. R, Samuel Butler and human long term memory: Is the cupboard bare?, Journal of Theoretical Biology. 258 (1): 156-164 (2009); Andrew A. M. The decade of the brain - further thoughts, Kybernetes. 26 (3): $255-264$ (1997)
} 
Quantum physics, albeit using a different terminology, expresses the same concept that the ancient masters were aware of: everything is one. Our universe, in fact, can be defined as a gigantic hologram. $^{198}$

Many physicists have begun to describe the universe in words that resemble Eastern philosophy. Bohm talks about the "dimension of consciousness beyond the concrete world of our ordinary experience". Capra discusses the "web of connectedness which cannot be described in words". Beauregard quotes from ancient Indian scriptures about the "illu sionary nature of separateness". John Wheeler summarized the holographic view of the universe when he said, "There may be no such thing as the 'glittering central mechanism of the universe.'... Not machinery but magic may be the better description of the treasure that is waiting". ${ }^{199}$

Our Civil Justice can be defined as a hologram. According to the best theory of Alessandro Fedrizzi, Professor of Quantum Physics, Heriot-Watt University, and Massimiliano Proietti, the facts can actually be subjective. ${ }^{200}$ The new picture of the world order, presented by French-British scientists, admits the complete absence of objective reality. According to this theory, the universe is a hologram woven by myriads of our minds. The same thing can be said regarding Civil Justice: the Civil Justice is a hologram woven by minds of trial's participants.

"Only if we can see the universe as a whole in which each part reflects the totality and in which the great beauty lies in its diversity, will we begin to understand who we are and where we are."- says Terzani. ${ }^{201}$ "But personality is not part of the universe, the universe is a part of personality, it is its quality. Such is the paradox of personalism". ${ }^{202}$

Francisco Di Biase ${ }^{203}$ proposes a quantum-informational holographic model of brainconsciousness-universe interactions based in the holonomic neural networks of Karl Pribram, in the holographic quantum theory developed by David Bohm, and in the non-locality property of the quantum field described by Hiroomi Umezawa. Francisco Di Biase considers this model an extension of the interactive dualism of Sir John Eccles, of an interconnection between brain and spirit by means of quantum microsites named dendrons and psychons. The scientist proposes a dynamic concept of consciousness seen as a holoinformational flux interconnecting the holonomic informational quantum brain dynamics, with the quantum informational holographic nature of the universe. This self-organizing flux is generated by the holographic mode of treatment of neuronal information and can be optimized through practices of deep meditation, prayer, and others states of higher consciousness that underlie the coherence of cerebral waves. In brain mapping studies performed during the occurrence of these harmonic states we can see the spectral array of brain waves highly synchronized and perfectly ordered like a unique harmonic wave, as if all frequencies of all neurons from all cerebral centers played the same symphony. This highly coherent brain state generates the non-local holographic informational cortical field of consciousness that interconnect the human brain and the holographic cosmos. The comprehension of this holonomic quantum informational nature of brain-consciousness-universe interconnectedness allows us to solve the mind-matter problem, the Justice problem unifying science, philosophy, and spiritual traditions in a more transdisciplinary, holistic, integrated paradigm. In this new arrangement cosmovision, consciousness and transpersonal phenomena becomes part of Science and of the very holoinformational nature of the Holographic Conscious Multiverse.

\footnotetext{
${ }^{198}$ Holography is simply a photographic technique that allows us to obtain three-dimensional images by superimposing light waves diffused by an object hit by a laser beam with others diffused by the same laser source. And reflected with a mirror; a hologram, in essence, is a 3D photograph produced with the support of a laser beam and a photographic film on which information is recorded. The peculiar characteristic of a hologram is that each portion of the whole contains the complete holographic image, each tiny fragment therefore contains a smaller, but intact, version of that image (even if the resolution of this image is proportional to the size of the fragment).

${ }^{199} \mathrm{https}: / /$ www.statpac.org/walonick/reality.htm

${ }^{200} \mathrm{https}: / /$ theconversation.com/quantum-physics-our-study-suggests-objective-reality-doesnt-exist-126805

${ }^{201}$ Terzani Tiziano, La fine è il mio inizio (2006)

${ }^{202}$ Berdyaev N. Slavery and Freedom. , 22, (1939)

${ }^{203} \mathrm{https} / / /$ www.researchgate.net/publication/253538121_A_HOLOINFORMATIONAL_MODEL_OF_CONSCIOUSNE SS_-_Quantum_Biosystems_2009_3_207-220
} 
Also we use the Stream of consciousness, which has become famous especially through the novels of James Joyce $(1882-1941) .{ }^{204}$ The sentence in the novel ${ }^{205}$ describing interactions with others is interesting: "Every life is in many days, day after day. We walk through ourselves, meeting robbers, ghosts, giants, old men, young men, wives, widows, brothers-in-love, but always meeting ourselves".

Modern scientists argue that the contents of consciousness are a subset of the experiences, emotions, thoughts and beliefs that are generated by non-conscious processes within our brains. This subset takes the form of a personal narrative, which is constantly being updated. The personal narrative exists in parallel with our personal awareness, but the latter has no influence over the former. They argue that it is the ability to communicate the contents of one's personal narrative and not personal awareness - that gives humans their unique evolutionary advantage. ${ }^{206}$

Teilhard de Chardin says: "While in the individual brain thought emerges from a system of nonthinking nerve fibers, in the case of the collective brain, on the other hand, each element is, in turn, an autonomous center of reflection". ${ }^{207}$

Russian Philosopher Pavel Nikolaevič Evdokimov ${ }^{208}$ says: "every part of the world vibrates empathically with the others. Thanks to this immanence, man is given to internalize, to expand his place, to identify it, from an ethical point of view, with the whole world". ${ }^{209}$

Following this let's say that every personal narrative (of a judge and of other trial's participants) communicates and every justice vibrates with the others as justice is part of the world. Thanks to this, a judge is given to internalize, to broaden every case, to identify it with the whole justice. Quantum mechanics finds that everything is broken down, not into mass, but into energy, where matter can be thought of as a "slowed down" version of energy. Modern sciences are in some ways very close to the doctrines of Heraclitus ${ }^{210}$. Werner Heisenberg, replacing the word "fire" of Heraclitus with the word "energy" repeats his statements verbatim from modern point of view. Heisenberg writes that the energy is in fact the substance of which all elementary particles, all atoms and therefore all things are made, and energy is what moves. Energy is a substance since its total sum does not change, and since elementary particles can actually be made up of this substance as it can be seen in many experiments on the production of elementary particles. Energy can be changed into motion, heat, light and tension. Energy can be called the fundamental cause of any change in the world". ${ }^{211}$

Energy can be called the fundamental cause of achieving civil justice.

What we have learned from Heisenberg's ideas is that we must lay down all our preconceptions about the Civil Justice that are the result of our reforms, experience and our wishes, and instead let science, mathematics show us the way.

A physical process caused by the organization of energy in the brain is consciousness. Evidence from neurobiology indicates that the brain operates on the principle of energetic processing and that a certain organization of energy in the brain, measured with information theoretic techniques, can be reliably predict the presence and level of consciousness. Since energy is causally efficacious in physical systems, it is reasonable to claim that consciousness is in principle caused by energetic activity and how it is dynamically organized in the brain.

\footnotetext{
${ }^{204}$ It was the French psychologist and philosopher Victor Egger (1848-1909), in the essay La parole intérieure. Essai de psychologie descriptive (1881), the first to speak of "stream of consciousness", a theme that developed even more under the influence of Sigmund Freud with his texts on psychoanalysis and the unconscious.

205 Joyce James, Ulysses, (1922)

${ }^{206}$ See Oakley David A, Halligan Peter here:

https://theconversation.com/what-if-consciousness-is-not-what-drives-the-human-mind-86785

${ }^{207}$ Chardin Pierre Teilhard, The Future of Man, 256 (1969)

${ }^{208}$ Paul Evdokimov, originally Russian Павел Николаевич Евдокимов (1901-1970) was an Orthodox theologian. Hе was professor of theology at the Institut de Théologie Orthodoxe Saint-Serge in Paris.

${ }^{209}$ See in: Dostoevskij e il problema del male, Città Nuova, Roma, 152 (1995).

${ }^{210}$ See also: https://fs.blog/2013/10/heraclitus-fragments/

${ }^{211}$ Heisenberg Werner, Physics and Philosophy: The Revolution in Modern Science, Harper \& Row, 1962
} 
It is proposed that a particular kind of activity occurs in human brains that causes our conscious experience. It is a certain dynamic organization of energetic processes having a high degree of differentiation and integration. This organization is recursively self-referential and results in a pattern of energetic activity that blossoms to a degree of complexity sufficient for consciousness. ${ }^{212}$ Legal consciousness can be called the fundamental cause of conventional existence of civil justice. Do we mean the personal legal consciousness?

To answer this question we would like to use the ideas of E. Schrodinger and Amir D. Aczel. ${ }^{213}$ E.Schrodinger writes: "consciousness is a singular of which the plural is unknown; that there is only one thing and that what seems to be a plurality is merely a series of different aspects of this one thing, produced by a deception." 214

Thirty years later: "There is obviously only one alternative, namely the unification of minds or consciousnesses. Their multiplicity is only apparent, in truth there is only one mind." 215

And thirty six years later, shortly before his death, he writes again (as a comment to a line in Upanishads):“...the plurality of sensitive beings is mere appearance (maya); in reality they are all only aspects of the one being." 216

According to Schrödinger, consciousness is fundamental and cannot be accounted for in terms of anything else.

Following Amir D. Aczel let's take an atom (composed of a center with protons and neutrons surrounded by a cloud of orbiting electrons). If one of its electrons loses two "units" of energy, approaching the nucleus, the atom emits two photons, or two particles of light, which, while moving away from each other, remain entangled. In what sense? If, after an indefinite period of time, one of the two photons is deflected, the other also suffers the same fate, albeit light years away.

It seems incredible that the slightest action on a particle immediately affects the twin particle even if it has been sent a universe away. Yet this extraordinary property seems to be an unavoidable feature of the most accredited and powerful theory of physics we have today: quantum mechanics. Known by the technical term of "entanglement", an interweaving of particles, it constitutes the greatest challenge for physicists, philosophers and social sciences since Werner Heisenberg began to plumb the mysteries of the infinitely small. It constitutes the greatest challenge for us here. Personal legal consciousnesses which are all only aspects of the one being can be called the fundamental cause of conventional existence of civil justice - here the answer.

"Legal consciousness is a collection of understood and/or imagined to have understood, legal awareness of ideas, views, feelings and traditions imbibed through legal socialization; which reflects as legal culture among given individual, or a group, or a given society at large. The legal consciousness evaluates the existing law and also bears in mind an image of the desired or ideal law" (Kaugia S). ${ }^{217}$

The Great Soviet Encyclopedia (1979) defined legal consciousness as "the sum of views and ideas expressing the attitude of people toward law, legality, and justice and their concept of what is lawful and unlawful. Legal consciousness is a form of social consciousness. Legal ideology, the system of legal views based on certain social and scientific viewpoints, is a concentrated expression of legal consciousness. The customs and feelings of people in relation to legal phenomena constitute the psychological aspect of legal consciousness" 218

\footnotetext{
${ }^{212} \mathrm{https} / / /$ www.frontiersin.org/articles/10.3389/fpsyg.2018.02091/full

${ }^{213}$ Aczel Amir D, Entanglement: The Greatest Mystery in Physics (September 18, 2002)

${ }^{214}$ Schrödinger E, What is Life? with Mind and Matter and Autobiographical Sketches. Cambridge University Press, Cambridge, 29 (1993). (Original editions: What is Life?, Cambridge, 1944, Mind and Matter, Cambridge, 1956)

${ }^{215}$ Opt. Cit, 129.

${ }^{216}$ Schrödinger E, My View of the World. Ox Bow Press, Woodbridge, Conn., 101 (1983) (original German edition: Meine Weltansicht, Paul Zsolnay Verlag, Wien 1961). This book includes two essays, Seek for the Road, written 1925, and What is Real?, written 1960.

${ }^{217} \mathrm{https}: / / \mathrm{www}$.juridicainternational.eu/index.php?id=12433

${ }^{218} \mathrm{https}$ ///encyclopedia2.thefreedictionary.com/Legal+Consciousness
} 
If a judge uses mindful discretion, the minds of trial's figures may be forced to choose one probability and that's the state the judge observes. In 1920, Niels Bohr (1885 - 1962) and others developed the Copenhagen Interpretation ${ }^{219}$, stating that a quantum particle doesn't exist in one state or another (as a wave or as a particle), but in all of its possible states at once. When we observe its state, the particle is forced to choose one probability, and that's the state we observe. The particle may be forced into a different observable state each time, which explains why a particle behaves erratically and can give differing results.

The "observer effect" states that the process of observing a particle changes the way the particle behaves. Following this way we could say that the judge leading the procedure changes the way the trial figures behave.

When we put these together and add mindfulness into the mix by taking into account the role of consciousness on the matter (energy) around us, we get an interesting set of theories.

Wolfgang Pauli ${ }^{220}$ was famous for what became known as the "Pauli effect," which manifested in the spontaneous breakdown of laboratory equipment whenever he entered the room. It also manifested in other ways, including mischievous events like chairs collapsing and train cars decoupling, to the detriment of those around him, but not to himself.

At one point in his life he collaborated with psychiatrist Carl Jung to study synchronicity, in part because of the "coincidences" surrounding his effect on matter. Not surprisingly, he believed in psychokinesis - the influencing of matter by thought - and that parapsychology was worthy of study. In fact, he was one of the first to consider and explore "quantum metaphysics," although Max Planck (1858 - 1957), the "father" of quantum physics, also believed in the metaphysical. Planck said, "I regard matter as derived from consciousness."

In our conditions, the special place of the problem of legal consciousness is explained by the fact that it is a source of justice, that is legal norms and relevant institutions, therefore it acts as a subject of mindfulness.

Legal consciousness is defined by Ewick and Silbey as the process by which people make sense of their experiences by relying on legal categories and concepts. ${ }^{221}$

Ivan Ilyin wrote:"Law needs legal consciousness in order to become a creative life force, and legal consciousness needs law in order to acquire a substantive basis and reality". ${ }^{222}$

Legal consciousness is not conceivable without personality, without human spirituality, but it presupposes human respect for law. For the evil will and predatory instinct of legal deniers or selfish people, legal order are necessary as a "muzzle".

\section{Ivan Ilyin about Legal Consciousness.}

Ilyin believes that legal consciousness is a synthesis of human feelings, the will of a person to comply with law and the law, the will to obedience to law, being loyal. A person as a social being must be aware of his rights and duties, what is forbidden to him. A person is obliged to recognize and respect the rights of each person individually, since his own rights live by the obligations and prohibitions of others, as well as his own rights restrict and bind other people's rights. It is quite obvious that a person has a special sense of righteousness, a sense of justice, a sense of

\footnotetext{
${ }^{219}$ The Copenhagen interpretation is the earliest and most widespread interpretation of quantum mechanics. It is inspired by the works carried out in the Danish capital by Niels Bohr and Werner Heisenberg, mainly, around 1927 and concerns the theory of quantum measurement, the principle of complementarity and wave-particle duality. In particular, the two scholars extended the probabilistic interpretation of the wave function proposed by Max Born, considering meaningless questions about the values of the quantities of a physical system before it is measured, as the measurement process randomly extracts one of the values allowed by the wave function that describes the quantum state of the system. This interpretation has received a better defined formulation since the 1950s, mainly thanks to Wolfgang Pauli. The expression "Copenhagen Interpretation" was introduced by Heisenberg in 1955.

${ }^{220}$ Wolfgang Pauli (1900-1958), an Austrian-Swiss physicist, won the Nobel Prize in physics in 1945 for the "Pauli Principle" involving spin theory.

${ }^{221}$ Ewick Patrizia; Silbey Susan, The Common Place of Law: Stories from Everyday Life. Chicago: University of Chicago Press, 22 (1998).

${ }^{222}$ Ilyin, I.A. О сущности правосознания, (On the essence of legal consciousness), Moscow, Volume I, 99 (1993).
} 
responsibility and a sense of freedom. Legal consciousness is a feeling respect for the law and legality; a sense of admiration for the legal authority and, accordingly, a sense of duty to him, a living sense of binding discipline.

Legal consciousness is a source of law and justice.

Legal consciousness is formed by three basic laws, formulated by I.A. Ilyin: comply with the rules of law, voluntary and fight for the new laws within the framework of the Constitution; gain freedom through voluntary self-binding and seek freedom only through law and the law; the law must be based on natural high sense of justice.

According to Ilyin, legal consciousness is the will of a person to observe law and the law, the will to be loyal to his behavior, the will to obey the law. However, legal consciousness is not at all reduced to the fact that a person "realizes" his rights.

A person is a social being, and if he forgets about it, then the violation of his rights will quickly remind him of this. Realizing his rights, a person is called upon to understand his duties; he must also understand what is forbidden to him. He is also called to understand that all other people and each person individually also have rights that he must recognize and respect; that his own rights live and feed on other people's obligations and prohibitions, just as other people's rights restrict and bind him.

In each state, there are several systems of legal consciousness, since the views on law are linked by the prevailing economic and political situation. Legal consciousness correlates legislation with really existing social relations, the interests of various groups and strata of the population, their moral ideas. Each subject develops its own attitude to law and state-legal activity. Therefore, along with public, it is appropriate to talk about group and individual sense of justice.

It is necessary that people in their life together observe some elementary, but sacred foundations of law and state. In the theory of I.A. Ilyin, they are formulated in the form of the axioms of legal consciousness. According to I.A. Ilyin, the axioms of legal consciousness are: the law of spiritual dignity; the law of autonomy; the law of mutual recognition. ${ }^{223}$

The axioms of legal consciousness are the basic values, which in life correspond to the basic ways of being, thining, motivating and acting. The form of human life is determined by the fact that a person is not just a living being, and not only a being endowed with psychic abilities, but a spiritual being.

Man, even the most primitive, harbors the will to spirit, the form of the spirit, the ability to spirit. The basis of normal legal consciousness is substantively substantiated, but socially self-sufficient respect of the subject to himself is a spiritually good force.

Justice serves the spirituality. State power is strong-willed power. This means that the mode of its action is by its very nature internal, psychic and, moreover, spiritual. ${ }^{224}$

So, according to the first and basic axiom of legal consciousness, spiritual dignity is the root of all true life, and self-respect is the source of state power and political health. This applies to both the individual and society as a whole.

Ilyin formulated the second axiom as follows: the basis of all legal and state life is the ability of a person to internal self-government, to spiritual, volitional self-discipline.

Autonomy or self-law is the true, basic form of the spirit; it is inherent in him the way he needs being and activity.

Spiritual life is self-activity in the realization of the highest spiritual values. A court is not an abstract unit, a power o just a psychophysiological individual, but a spiritual being, for whom autonomy is needed like air. To be a judge means to lead an autonomous spiritual life, to have an autonomous sense of justice and to conduct every trial with it.

Ilyin is convinced that every citizen should have independent convictions about good and evil, about the essence and purpose of man, about the highest goal of law and the state, a conscious and mature will.

\footnotetext{
${ }^{223}$ Ilyin, I.A. Writings: in 2 volumes, Moscow, Volume 1, 211 (1991)

${ }^{224}$ lyin Ivan, Axioms of Power, from the book On the Essence of Legal Consciousness, Munich (1956)
} 
True autonomy is available only to those who have achieved spiritual self-assertion and asserted spiritual dignity in themselves. This is the connection between the first two axioms of legal consciousness

The third axiom says that the basis of any rule of law state is the mutual spiritual recognition of people, their respect and trust in each other.

It is impossible for a person to live on earth without entering into relationships with other people. A clash of interests engenders a competition between those concerned, and this competition must find its end and resolution. It can be resolved in ways worthy of the spirit and in ways not worthy of it. Law is possible only where there is a living relationship between people: law emerges for the first time as the relationship of spirit to spirit. This relationship is defined as mutual spiritual recognition. In his works I.A. Ilyin especially emphasizes the idea that without legal consciousness one cannot live by law, enter into legal relations with other people, maintain law and order, compete for rights, create a court, organize private societies (scientists, joint-stock companies, clubs, cooperatives ) and public organizations (legislative assemblies), participate in elections, be an official, judge, president and lawmaker.

Legal consciousness is necessary in judicial and political life as the main "tool". It cannot be assumed that it is inherent in all people from the beginning and is the same: it must be educated and strengthened in people through the mindfulness. It is necessary to instill in people a confident, unshakable feeling that they are spiritual beings, that they are recognized as subjects of law, that they have spiritual dignity, that they are called to self-control and self-government, that they are called to mutual respect and trust, that state power respects them and trusts them and that they are called to respond to her with the same feelings...

We've tested the concept of Ivan Ilyin. It shows multiple parallels to and compatibilities with wellestablished legal \scientific doctrines of Civil Justice and Discretion, Thought, Attention, Awakening, Consciousness, Mindfulness. Ivan Ilyin would say that conventional existence of Civil Justice depends on legal consciousness.

Something that produces the interaction (Civil Justice), that connecting something that allows justice to act through civil procedural form, gradual development in the courtroom is legal consciousness (consciousness, mindfulness).

\section{Conclusion}

The conventional existence of civil justice is a big job. Not an impossible job, but a big one. The present article, however, may be about the illusion of justice and not the reality of it.

Thus, it may be that what many in our society want lawmakerljudge to stand for is an illusion that there is equal access, that there is equal justice, when they are unwilling to pay the price to ensure that it actually occurs. We would say, therefore, that it is important to try and focus on what we want. The power of thoughts, words, the power to color even the dullest sky, the just discretion even there isn't the reality of justice, to shock our eyes so much as to paint the rainbow on a wet day, making us dream of the end of injustice and a new beginning of justice.. With the waiting for justice that starts gray, the thought of Jean-Paul Hernandez ${ }^{225}$ saves us: "Caress is the physicality of a blessing ..."226 Following this we say:"Mindful judicial discretion is the physicality of justice..." It is enough to end every trial with decisions that are mindful, with the mindful look in the eyes of trial participants. We urge every lawmakerljudge: use precise thinking, use legal consciousness (consciousness, mindfulness). Thought is the ultimate product of the evolutionary process and it is subject to evolution so it can continually improve. Edgar Morin ${ }^{227}$ says: "Thought must establish frontiers and cross them, open concepts and close them, go from the whole to the parts and from the

\footnotetext{
${ }^{225}$ Lecturer, Faculty of History and Cultural Heritage, Pontifica Universita Gregoriana, Italy.

226“"La carezza è la fisicità di una benedizione”, in: Hernandez Jean-Paul, Mettere ordine nella propria vita: sei vie della Sapienza, https://notedipastoralegiovanile.it/images/DOSSIER_PDF/DOSSIER_NPG__Mettere_ordine_nella_propria_vita_Hernndez.pdf

${ }^{227}$ Edgar Morin, pseudonym of Edgar Nahoum (1921), is a French philosopher and sociologist. He is known for the transdisciplinary approach with which he deals with a wide range of topics, including epistemology.
} 
parts to the whole, doubt and believe, it must reject and fight the contradiction but, at the same time, it must take charge and nourishment ". And he continues: "Thought is an uninterrupted dialogic dynamism, navigation between Scylla and Charybdis ${ }^{228}$ towards which it drags every hegemony of one of the antagonistic processes".

May there be this awareness when a lawmakerljudge uses his thoughts! "Those who act with approximation also get used to speaking with approximation, and coarse, imprecise and slovenly speaking also involves thinking in this indeterminacy [...] Being precise and clear in one's thoughts is the pledge of spiritual freedom". 229

Europe and Russia have had to endure many troubles and trials over the last thousand years. Wars tormented them, famine, epidemics, disasters, financial crises, earthquakes, environmental disasters. The terrorist attacks stunned them. They endured everything, Europe and Russia overcame everything, they only grew stronger from the trials. But now ... The man has stolen food for 50 euros. Of course, neither Russia nor Europe can stand this ..

With this phrase I would like to disarm you, dear readers. Because from a legal and moral points of view, it is obvious that an elderly man who lost his business during the Coronavirus-19 pandemic, who has reached extreme poverty, is worthy of pity, but private property is sacred. And the law should protect it. Nevertheless, what kind of judicial decision would mean justice here?

So I bless you with the words of Fyodor N. Plevako ${ }^{230}$ one who lives in words, makes them live: "The legislator knows that there are cases when the interests of higher justice preclude the application of the law. The legislator knows that there are cases when to judge by the measure of the law means to laugh at the law and publicly commit an act of lawlessness".

Of course, we must be patient. It takes time to get to the simplicity of judicial discretion as the justice's language. It takes time to reach the innocence of every justice's commitment. It takes time to achieve justice in a trial and even more time to laugh at what you (as a judge) have just achieved. Laughing at your knowledge as at your ignorance. Laughing with mindful look in your eyes, mindful lawyer in your voice, rain in your decision. Because sometimes it rains in your decisions. A thin rain slides on the pages, falls on the heart... (following Christian Bobin)

The COVID-19 pandemic is requiring lawmakersljudges to make profoundly important decisions decisions which often have immediate impacts on our rights and freedoms and which will fundamentally shape our society and economy for years to come. Robust scrutiny and debate will improve the quality of these decisions and strengthen public trust in them.

We need Discretion to step justice up, not shut it down, in the pandemic.

The knowledge of the interconnectedness of everything in the universe will expose us to the clear understanding that energy is the central matrix of reality and can be dissipated consciously or unconsciously to affect both mental and extra-mental realities. An awareness of this immanent nature within and around us will aid greater interaction and advancement in interdisciplinary studies that will improve justice and society.

Author: Papkova Olga, Kandidat nauk, Moscow State University, Russia; PhD, University of Pavia, Italy; e-mail: olga.papkova@unipv.it

\footnotetext{
${ }^{228}$ Scylla and Charybdis, in Greek mythology, two immortal and irresistible monsters who beset the narrow waters traversed by the hero Odysseus in his wanderings described in Homer's Odyssey, Book XII.

${ }^{229}$ Florenskij Pavel A, Letters from the Gulag (English Edition), (6 Nov. 2020)

${ }^{230}$ Fyodor N. Plevako (1842 - 1908), Moscow- Russian lawyer and judicial orator, actual state councilor. For Russia he was Cicero, and for Moscow - Zlatoust (Ioann Zlatoust (in Russian: Иоанн Златоуст, literally Giovanni Bосca d'oro, Russified version of John Chrysostom) See: The newspaper "Early morning" (December 24, 1908).
} 